\title{
Time trends of daily maximum and minimum temperatures in Catalonia (ne Spain) for the period 1975-2004
}

\author{
M. D. Martínez, ${ }^{a}$ C. Serra, ${ }^{b}$ A. Burgueño ${ }^{c}$ and X. Lana ${ }^{b *}$ \\ a Departament de Física Aplicada, Universitat Politècnica de Catalunya, Av. Diagonal 649, 08028 Barcelona, Spain \\ b Departament de Física i Enginyeria Nuclear, Universitat Politècnica de Catalunya, Av. Diagonal 647, 08028 Barcelona, Spain \\ c Departament d'Astronomia i Meteorologia, Facultat de Física, Universitat de Barcelona, C. Martí i Franquès 1, 08028 Barcelona, Spain
}

\begin{abstract}
Daily maximum and minimum temperatures, $T_{\max }$ and $T_{\min }$, and diurnal temperature range, DTR, from 37 temperature stations in Catalonia (NE Spain) are analyzed to detect significant daily time trends for the period 1975-2004. The homogeneity of the series is tested by means of the Standard Normal Homogeneity, the Buishand range and the Pettitt tests. The lack of randomness of the series, suggesting time trends, is also investigated by means of the Von Neumann ratio test. The daily time trends obtained and their spatial and temporal patterns are mainly in agreement with overall time trends recently derived for the Northern Hemisphere. The results indicate generalized increasing annual trends of daily $T_{\max }$ and $T_{\min }\left(0.5^{\circ} \mathrm{C} / \mathrm{decade}\right)$, especially relevant in spring and summer, with values reaching $0.8-0.9^{\circ} \mathrm{C} / \mathrm{decade}$, and also remarkable for $T_{\max }$ in winter $\left(0.7^{\circ} \mathrm{C} / \mathrm{decade}\right)$. In autumn, however, average trends point at a decrease in $T_{\max }\left(-0.5^{\circ} \mathrm{C} / \mathrm{dec}\right.$ ade $)$. As a result, an average annual decreasing trend of DTR is found, particularly relevant in autumn $\left(-0.9^{\circ} \mathrm{C} / \mathrm{decade}\right)$. Several periods with an outstanding number of stations showing significant positive time trends are detected and analyzed during the spring and summer seasons both for daily $T_{\max }$ and $T_{\min }$. The only period with a relevant number of significant negative trends is detected in February for daily $T_{\min }$, thus implying a significant increasing trend of DTR during this short winter period. Comparisons are established with large- and regional-scale temperature trends, paying attention to the west Mediterranean atmospheric dynamics change. Copyright (c) 2009 Royal Meteorological Society
\end{abstract}

KEY WORDS Global and regional warming; daily $T_{\max }$ and $T_{\min }$; DTR; time trends; annual and seasonal scales; homogeneity and randomness tests; NE Spain

Received 23 April 2008; Revised 11 December 2008; Accepted 26 January 2009

\section{Introduction}

The effects of global warming on the temperature regimes, mainly due to the increase in the atmospheric greenhouse effect (Trenberth et al., 2007), are widely recognized and many time trend analyses at global, continental, regional and local scales can be cited (Table I). These studies, as many others on temperature trends, have preference for the annual, seasonal and monthly timescales. In this manner, spells of calendar days with significant time trends cannot be detected. The assessment of these daily time trends would be very relevant when future simulations of daily temperature scenarios constrained by the greenhouse gases (GHG) emission would be performed. While at present the simulations mostly operate at seasonal or annual scale (Schubert et al., 1998; McGuffie et al., 1999; Gibelin and Déqué, 2003; Bell et al., 2004; Giorgi et al., 2004; Kjellström, 2004; Räisänen et al., 2004; Sánchez et al., 2004; Ghan and Shippert, 2006), simulations at a shorter time scale are recent and scarce (Meehl and Tebaldi, 2004).

\footnotetext{
* Correspondence to: X. Lana, Departament de Física i Enginyeria Nuclear, Universitat Politècnica de Catalunya, Av. Diagonal 647, 08028 Barcelona, Spain. E-mail: francisco.javier.lana
}

The present study is focused on analyzing daily temperature trends at a small regional scale, Catalonia (NE Spain), along the 1975-2004 recording period. As a reference, according to global climate studies (Trenberth et al., 2007), the global annual temperature rise due to anthropogenic activities for the 1975-2004 period is $0.5^{\circ} \mathrm{C}$, with a smoothed annual value that departs from the monotonic positive increase close to 1984 , and it is almost constant close to 1992 .

The complex behavior of the atmospheric dynamics makes it difficult and inappropriate to directly transfer the global increase in GHG emission into local or regional temperature regime changes. Then, the schema undertaken is the detailed analysis of time trends affecting calendar day temperatures, instead of annual, seasonal or monthly averaged temperatures, for different locations. Thus, it could be assessed which locations and specific periods of the year are affected by significant temperature trends. Additionally, it could be stated for instance if global warming causes a lengthening of hot summers, relatively warm winters or a smoothing of temperature contrasts between spring and summer and/or summer and autumn. Owing to the daily scale of the analysis, it would be possible to detect what calendar day spells contribute to these patterns. 
Table I. Selected references on temperature time trends at different spatial scales, published in the 1996-2008 period.

\begin{tabular}{|c|c|c|c|c|}
\hline Regions & $\begin{array}{l}\text { Number of } \\
\text { stations }\end{array}$ & Time period & Trends of & Reference \\
\hline Globe & 5400 & $1950-1994$ & $\begin{array}{l}\text { Seasonal and annual } T_{\text {mean }}, \\
T_{\max } \text { and } T_{\min }\end{array}$ & Easterling et al. (1997) \\
\hline Globe & $\sim 1000$ & $1856-1998$ & Seasonal and annual $T_{\text {mean }}$ & Jones et al. (1999) \\
\hline Most of the Globe & $\sim 300$ & $1946-1999$ & Five temperature indices & Frich et al. (2002) \\
\hline Globe & 5159 & $1851-2000$ & Seasonal and annual $T_{\text {mean }}$ & Jones and Moberg (2003) \\
\hline Globe & & $1861-1999$ & Annual $T_{\text {mean }}$ & Salinger (2005) \\
\hline Globe & 2223 & $1951-2003$ & $\begin{array}{l}\text { Seasonal and annual extreme } \\
T_{\max } \text { and } T_{\min }, \text { DTR and } 11 \\
\text { temperature indices }\end{array}$ & Alexander et al. (2006) \\
\hline Europe & 90 & $1891-1990$ & $\begin{array}{l}\text { Monthly, seasonal and annual } \\
T_{\text {mean }}\end{array}$ & $\begin{array}{l}\text { Schönwiese and Rapp } \\
\text { (1997) }\end{array}$ \\
\hline United States & 361 & $1900-1996$ & $\begin{array}{l}\text { Annual extreme percentiles of } \\
T_{\max } \text { and } T_{\min }\end{array}$ & Klein Tank et al. (2002) \\
\hline Europe & 199 & $1946-1999$ & Daily $T_{\max }, T_{\min }$ and $T_{\text {mean }}$ & Klein Tank et al. (2003) \\
\hline Europe & 86 & $1946-1999$ & $\begin{array}{l}\text { Six indices of daily cold and } \\
\text { warm temperature extremes }\end{array}$ & Klein Tank et al. (2003) \\
\hline Europe & 185 & $1946-1999$ & $\begin{array}{l}\text { Variance and skewness of daily } \\
T_{\text {mean }}\end{array}$ & Klein Tank et al. (2005) \\
\hline Europe & 75 & $1901-2000$ & $\begin{array}{l}\text { Summer and winter percentiles } \\
\text { of } T_{\max } \text { and } T_{\min }\end{array}$ & Moberg et al. (2006) \\
\hline Spain and Canary Islands & 11 & $1901-1989$ & $\begin{array}{l}\text { Seasonal and annual } T_{\max }, T_{\min } \\
\text { and DTR }\end{array}$ & Oñate and Pou (1996) \\
\hline $\begin{array}{l}\text { Central and southeastern } \\
\text { Europe }\end{array}$ & & $1951-1990$ & $\begin{array}{l}\text { Seasonal and annual } T_{\text {mean }} \\
T_{\max }, T_{\min } \text { and DTR }\end{array}$ & Brázdil et al. (1996) \\
\hline NE United States & 22 & $1951-1993$ & $\begin{array}{l}\text { Number of days with } T_{\max } \text { and } \\
T_{\min } \text { above and below some } \\
\text { thresholds }\end{array}$ & DeGaetano (1996) \\
\hline Israel & 40 & $1964-1994$ & $\begin{array}{l}\text { Daily, monthly and annual } \\
T_{\max }, T_{\min }, \text { and DTR }\end{array}$ & Ben-Gai et al., 1999 \\
\hline Venezuela and Colombia & 14 & $1918-1990$ & Monthly $T_{\max }, T_{\min }$, and DTR & Quintana-Gómez (1999) \\
\hline Canada & 210 & $1900-1998$ & $\begin{array}{l}\text { Daily and seasonal } T_{\max } \text { and } \\
T_{\min } 1 \text { th,5th,10th,90th,95th and } \\
99 \text { th percentiles }\end{array}$ & Bonsal et al. (2001) \\
\hline New Zealand & 22 & $1951-1998$ & $\begin{array}{l}\text { 95th percentile of } T_{\max }, 5 \text { th } \\
\text { percentile of } T_{\min } \text { and four } \\
\text { temperature indices }\end{array}$ & $\begin{array}{l}\text { Salinger and Griffiths } \\
\text { (2001) }\end{array}$ \\
\hline $\begin{array}{l}\text { SE Asia and south } \\
\text { Pacific }\end{array}$ & 38 & $1961-1998$ & $\begin{array}{l}\text { Frequency of } T_{\max } \text { and } T_{\min } \\
\text { 99th and 1th percentiles }\end{array}$ & Manton et al. (2001) \\
\hline South Korea & 12 & $1954-1999$ & $\begin{array}{l}\text { Mean seasonal and annual } \\
T_{\max }, T_{\min } \text { and DTR }\end{array}$ & Jung et al. (2002) \\
\hline China & 196 & $1951-1999$ & $\begin{array}{l}\text { Annual number of hot, frost, } \\
\text { warm, cool days, and warm } \\
\text { and cool nights }\end{array}$ & Zhai and Pan (2003) \\
\hline Iceland & 4 & $1871-2001$ & Seasonal and annual $T_{\text {mean }}$ & Hanna et al. (2004) \\
\hline South Africa & 26 & $1960-2003$ & $\begin{array}{l}\text { Monthly, seasonal and annual } \\
T_{\text {mean }}, T_{\max }, T_{\min } \text { and six } \\
\text { temperature indices }\end{array}$ & $\begin{array}{l}\text { Kruger and Shongwe } \\
(2004)\end{array}$ \\
\hline Poland & 51 & $1951-2000$ & Monthly $T_{\text {mean }}$ & $\begin{array}{l}\text { Degirmendžić et al. } \\
\text { (2004) }\end{array}$ \\
\hline Italy & 50 & $1866-1996$ & Seasonal and annual $T_{\text {mean }}$ & Brunetti et al. (2004) \\
\hline Italy & Up to 67 & $1802-2003$ & $\begin{array}{l}\text { Seasonal and annual } T_{\text {mean }} \\
T_{\max } \text { and } T_{\min }\end{array}$ & Brunetti et al. (2006) \\
\hline $\begin{array}{l}\text { Central and western } \\
\text { Europe }\end{array}$ & 81 & $1901-1999$ & $\begin{array}{l}\text { Seasonal } T_{\max } \text { and } T_{\min } \text { 90th } \\
\text { and 10th percentiles }\end{array}$ & Moberg and Jones (2005) \\
\hline $\begin{array}{l}\text { Central and northern } \\
\text { South America }\end{array}$ & 48 & $1961-2003$ & $\begin{array}{l}\text { Annual extreme } T_{\max } \text { and } \mathrm{i}_{\min } \text {, } \\
\text { DTR and six temperature } \\
\text { indices }\end{array}$ & Aguilar et al. (2005) \\
\hline
\end{tabular}


Table I. (Continued).

\begin{tabular}{|c|c|c|c|c|}
\hline Regions & $\begin{array}{l}\text { Number of } \\
\text { stations }\end{array}$ & Time period & Trends of & Reference \\
\hline Western Germany & 232 & $1958-2001$ & $\begin{array}{l}\text { Seasonal and annual } T_{\max } \text { 90th } \\
\text { percentile and } T_{\min } 10 \text { th } \\
\text { percentile, and two temperature } \\
\text { indices }\end{array}$ & $\begin{array}{l}\text { Hundecha and Bárdossy } \\
\text { (2005) }\end{array}$ \\
\hline Castilla-León (Spain) & 171 & $1961-1997$ & $\begin{array}{l}\text { Monthly, seasonal and annual } \\
T_{\operatorname{mean}}, T_{\max } \text { and } T_{\min }\end{array}$ & $\begin{array}{l}\text { Del Río et al. (2005, } \\
\text { 2007) }\end{array}$ \\
\hline Egypt & 19 & $1987-2000$ & Summer months $T_{\text {mean }}$ & $\begin{array}{l}\text { Hasanean and Abdel } \\
\text { Basset (2006) }\end{array}$ \\
\hline Tibetan plateau & 66 & $1961-2003$ & $\begin{array}{l}\text { Daily and monthly } T_{\max }, T_{\min } \text {, } \\
\text { and DTR }\end{array}$ & Liu et al. (2006) \\
\hline South and west Africa & 63 & $1961-2000$ & $\begin{array}{l}\text { Monthly highest and lowest } \\
T_{\max }, T_{\min } \text { and DTR, together } \\
\text { to } 11 \text { temperature indices }\end{array}$ & New et al. (2006) \\
\hline Valencia (Spain) & 8 & $1958-2003$ & $\begin{array}{l}\text { Summer months } T_{\text {mean }}, T_{\max }, \\
T_{\min }\end{array}$ & Miró et al. (2006) \\
\hline California (USA) & 331 & $1950-2000$ & $\begin{array}{l}\text { Annual } T_{\text {mean }}, T_{\max }, T_{\min } \text { and } \\
\text { DTR }\end{array}$ & LaDochy et al. (2007) \\
\hline Spain & 22 & $1850-2005$ & $\begin{array}{l}\text { Seasonal and annual } T_{\text {mean }}, \\
T_{\max }, T_{\min }\end{array}$ & Brunet et al. (2007a) \\
\hline Switzerland & 12 & $\begin{array}{l}1901-2000 \\
1975-2004\end{array}$ & $\begin{array}{l}\text { Seasonal and annual } T_{\text {mean }} \text {, } \\
T_{\max }, T_{\min }\end{array}$ & $\begin{array}{l}\text { Rebetez and Reinhard } \\
\text { (2008) }\end{array}$ \\
\hline $\begin{array}{l}\text { Fabra observatory } \\
\text { (Spain) }\end{array}$ & 1 & $1917-1998$ & Daily $T_{\max }$ and $T_{\min }$ & Serra et al. (2001) \\
\hline Athens (Greeze) & 1 & $1897-2001$ & $\begin{array}{l}\text { Seasonal and annual } T_{\max }, T_{\min } \\
\text { and DTR }\end{array}$ & Founda et al. (2004) \\
\hline Hohenheim (Germany) & 1 & $1878-2002$ & $\begin{array}{l}\text { Monthly, seasonal and annual } \\
T_{\text {mean }}, T_{\max }, T_{\min } \text { and four } \\
\text { temperature indices }\end{array}$ & $\begin{array}{l}\text { Wulfmeyer and } \\
\text { Henning-Müller (2006) }\end{array}$ \\
\hline
\end{tabular}

Trends of daily maximum and minimum temperature, $T_{\max }$ and $T_{\min }$, and daily temperature range (DTR) are evaluated for every station and every calendar day of the year. In spite of the expected complex evolution of every calendar day temperature, linear time trends are a good approach because of the observed smooth annual temperature increase along the analyzed period. For longer term series, due to well known changes in trends, a more suitable technique of fit either by automatic selection of breakpoints and fit of straight lines or by nonlinear models, instead of a simple linear evolution, should have been taken into account (Tomé and Miranda, 2004; Mills, 2006). Trends are determined by two methods. The first is based on a linear regression of the series. This method has some shortcomings when data have an irregular evolution in time, and the trends derived could be then submitted to relevant uncertainties. In this case, the second method, based on the Kendall-tau algorithm, offers more reliable estimations. Trends deduced by both methods are very similar when time irregularities are not very relevant. The statistical significance of every daily time trend is qualitatively investigated for every station by means of the Von Neumann ratio test and quantified by the Mann-Kendall and Kendall-tau tests.
A complementary point of view of the climatic change effects in Catalonia is given by previous analyses on annual precipitation and dry spells, for the years 1950-2000. These analyses have shown how these magnitudes are sensible to the present climatic change. Field significant trends were detected in the number of rainy days for percentiles up to 75 , all local trends being negative. Field significant trends were also detected in daily rain intensity, whatever the threshold level, with positive and negative trends. The relevance index indicated an increasing contribution of light and moderate daily episodes to the annual amounts. At the same time, annual rain amounts were characterized by significant local (negative) trends for 2 out of the 39 rain gauges analyzed (Martínez et al., 2007) The number of dry spells per year depicted significant trends for the annual and winterhalf series, with an overall decreasing trend for 5 and $10 \mathrm{~mm} /$ day threshold (Serra et al., 2006).

The contents of the manuscript are organized as follows. Section 2 introduces the dataset and several quality controls to detect incoherent data. Different homogeneity tests are applied in Section 3. The results of time trend analysis of daily $T_{\max }, T_{\min }$ and DTR are presented in Section 4 as follows: first, the average annual trends on daily $T_{\max }, T_{\min }$ and DTR for every station, 
together with the average annual and seasonal trends for the whole network; second, the spatial average trend for every calendar day; third, histograms depicting the number of stations with significant time trends for every calendar day. From these histograms, it is straightforward to detect a few periods visually (months, weeks and even a few days) for which an outstanding number of stations have positive or negative significant time trends. After that, an average time trend (ATT) is estimated for every relevant time period. A more detailed description is obtained by analyzing the average trends and the number of significant trends for all stations within each period. Comparisons are established with large- and regionalscale temperature trends in Section 5, paying attention to West Mediterranean atmospheric dynamics change and the main conclusions are summarized in Section 6.

\section{Data set}

The analysis is applied to a series of daily $T_{\max }, T_{\min }$ and DTR recorded at 37 meteorological stations in Catalonia (NE Spain), pertaining to the Agencia Estatal de Meteorología (Ministry of Environment, Spanish Government), with recording period from 1975 to 2004. Fabra Observatory (Reial Acadèmia de Ciències i Arts de Barcelona) is included as station 77. Although temperature series are available since 1950 for many stations, data previous to 1975 have not been considered due to the sharp slope change in temperature records around 1975, well observed from annual global temperature analyses (Trenberth et al., 2007). On the one hand, this sharp change in time trends could mask other lacks of homogeneity, attributable to alterations of station environment and changes of recording devices or data collection procedures, which should be detected by tests of homogeneity. On the other hand, the evaluation of time trends of the temperature regime for the period 1975-2004 would be also masked by considering a longer recording period.

Figure 1a describes the main orographic features of Catalonia. Its regional climate is protected against cold north and northwestern outbreaks by the Pyrenees Range, which may generate the Föhn effect on the north of the country. A long coast of some $400 \mathrm{~km}$ facilitates the influence of Mediterranean air masses, especially the summer sea breezes. The Littoral and Pre-Littoral chains diminish this influence, and together with the Pyrenees Range delimit the Central Basin, which remains protected from Mediterranean influences. Figure $1 \mathrm{~b}$ depicts the locations of the stations. As only stations with a good recording continuity have been considered, the northern part of the domain is not well covered and the spatial distribution is not optimum. It has to be remembered that continuity of the records is highly recommended for right assessments of data homogeneity and accurate evaluation of trends. Figure 1(c) depicts the number of available stations for every recording year. Table II lists station codes, average values and standard deviations of
Table II. Expected values of daily $T_{\max }$ and $T_{\min }$ and DTR $\left(<T_{\max }>,<T_{\min }>,<\mathrm{DTR}>\right)$ and their standard deviations $\left(\mathrm{SD}_{\max }, \mathrm{SD}_{\min }\right.$ and $\left.\mathrm{SD}_{\mathrm{DTR}}\right)$ for the 37 stations (years 1975-2004).

\begin{tabular}{|c|c|c|c|c|c|c|}
\hline Code & $\begin{aligned}< & T_{\max }> \\
& \left({ }^{\circ} \mathrm{C}\right)\end{aligned}$ & $\begin{array}{l}\mathrm{SD}_{\max } \\
\left({ }^{\circ} \mathrm{C}\right)\end{array}$ & $\begin{aligned}< & T_{\min }> \\
& \left({ }^{\circ} \mathrm{C}\right)\end{aligned}$ & $\begin{array}{c}\mathrm{SD}_{\min } \\
\left({ }^{\circ} \mathrm{C}\right)\end{array}$ & $\begin{array}{c}<\text { DTR }> \\
\left({ }^{\circ} \mathrm{C}\right)\end{array}$ & $\begin{array}{c}\mathrm{SD}_{\mathrm{DTR}} \\
\left({ }^{\circ} \mathrm{C}\right)\end{array}$ \\
\hline 1 & 21.1 & 6.8 & 12.1 & 5.6 & 9.0 & 3.1 \\
\hline 3 & 20.9 & 5.9 & 11.1 & 6.0 & 9.8 & 3.0 \\
\hline 4 & 21.2 & 6.6 & 14.7 & 5.8 & 6.5 & 2.4 \\
\hline 5 & 19.3 & 7.8 & 8.8 & 5.7 & 10.5 & 4.0 \\
\hline 6 & 20.5 & 7.5 & 9.5 & 6.2 & 10.9 & 4.0 \\
\hline 7 & 19.3 & 7.7 & 7.7 & 6.0 & 11.5 & 3.7 \\
\hline 10 & 20.5 & 6.5 & 10.6 & 6.3 & 9.9 & 3.0 \\
\hline 11 & 21.3 & 5.8 & 13.3 & 5.7 & 7.9 & 2.4 \\
\hline 12 & 20.2 & 5.6 & 11.4 & 5.8 & 8.8 & 2.3 \\
\hline 15 & 17.6 & 7.9 & 6.9 & 6.3 & 10.6 & 3.5 \\
\hline 16 & 16.1 & 6.6 & 9.5 & 6.1 & 6.7 & 2.7 \\
\hline 17 & 20.2 & 6.9 & 10.3 & 6.0 & 9.9 & 3.0 \\
\hline 18 & 18.6 & 7.4 & 6.0 & 6.4 & 12.6 & 4.0 \\
\hline 20 & 21.7 & 7.1 & 8.5 & 6.6 & 13.2 & 4.1 \\
\hline 21 & 20.7 & 7.0 & 9.4 & 6.3 & 11.4 & 3.7 \\
\hline 22 & 20.9 & 6.8 & 8.3 & 6.5 & 12.6 & 3.8 \\
\hline 23 & 18.1 & 6.1 & 11.2 & 5.8 & 6.9 & 2.2 \\
\hline 25 & 22.4 & 8.2 & 8.8 & 6.2 & 13.6 & 4.9 \\
\hline 26 & 21.0 & 5.9 & 10.4 & 6.3 & 10.6 & 3.3 \\
\hline 28 & 19.1 & 7.0 & 11.3 & 6.1 & 7.8 & 2.9 \\
\hline 29 & 19.2 & 7.5 & 6.0 & 6.3 & 13.2 & 4.6 \\
\hline 31 & 19.8 & 7.5 & 7.1 & 6.1 & 12.6 & 4.1 \\
\hline 32 & 19.6 & 8.3 & 6.9 & 6.5 & 12.7 & 4.3 \\
\hline 34 & 20.4 & 6.7 & 8.5 & 6.4 & 11.9 & 3.8 \\
\hline 35 & 21.4 & 7.0 & 8.3 & 6.5 & 13.1 & 4.1 \\
\hline 36 & 19.4 & 5.5 & 11.9 & 5.9 & 7.5 & 2.8 \\
\hline 42 & 19.6 & 8.6 & 6.9 & 6.7 & 12.8 & 4.3 \\
\hline 43 & 20.5 & 9.1 & 7.1 & 7.0 & 13.3 & 4.9 \\
\hline 56 & 19.9 & 9.5 & 8.4 & 6.9 & 11.4 & 4.4 \\
\hline 59 & 19.4 & 8.8 & 8.3 & 6.5 & 11.1 & 3.8 \\
\hline 60 & 20.1 & 9.0 & 7.4 & 6.8 & 12.7 & 4.6 \\
\hline 68 & 20.8 & 7.9 & 10.4 & 5.9 & 10.5 & 3.8 \\
\hline 69 & 22.6 & 8.2 & 10.5 & 7.0 & 12.1 & 4.3 \\
\hline 71 & 19.7 & 8.4 & 10.2 & 6.5 & 9.5 & 3.7 \\
\hline 73 & 22.1 & 8.5 & 10.2 & 6.3 & 11.3 & 4.0 \\
\hline 75 & 22.8 & 6.8 & 12.3 & 5.8 & 10.6 & 3.4 \\
\hline 77 & 18.9 & 6.7 & 11.4 & 5.6 & 7.5 & 2.5 \\
\hline
\end{tabular}

daily $T_{\max }, T_{\min }$ and DTR for the whole 30 -year recording period.

Data quality is checked by several tests applied to the series of daily $T_{\max }$ and $T_{\min }$, in agreement with rules proposed by Aguilar et al. (2003) and Brunet et al. (2007b, 2008). Five different types of quality controls are applied. First, gross errors ( $T_{\max }$ and $T_{\min }$ exceeding unlikely temperatures) are checked. Second, data tolerance is checked by searching for periods longer than a certain number of consecutive days with exactly the same temperatures. Moreover, daily temperature records exceeding a certain number of standard deviations from average values, both quantities computed for every calendar day, have been also considered as not reliable data. Third, a revision of internal consistence is done, verifying that daily $T_{\max }$ 
(a)

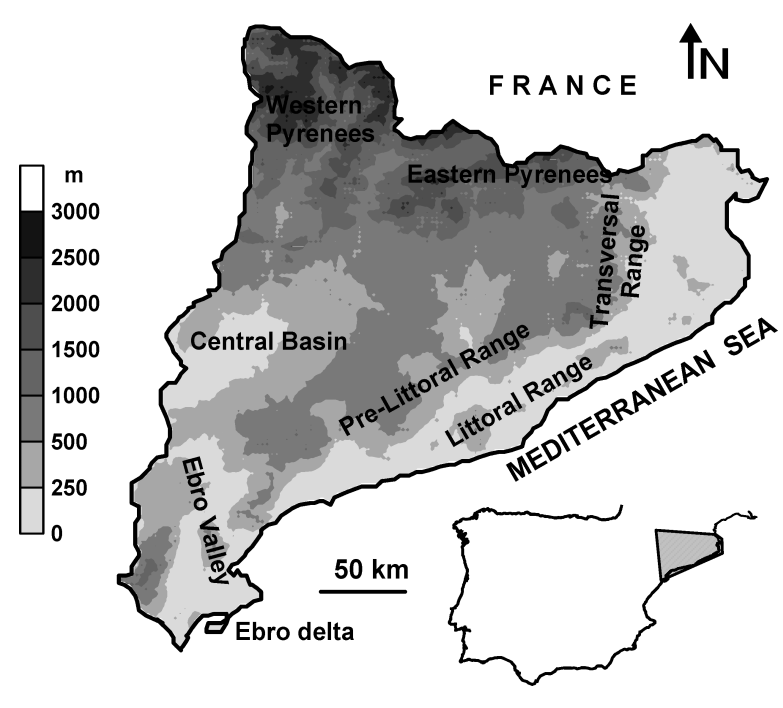

(b)

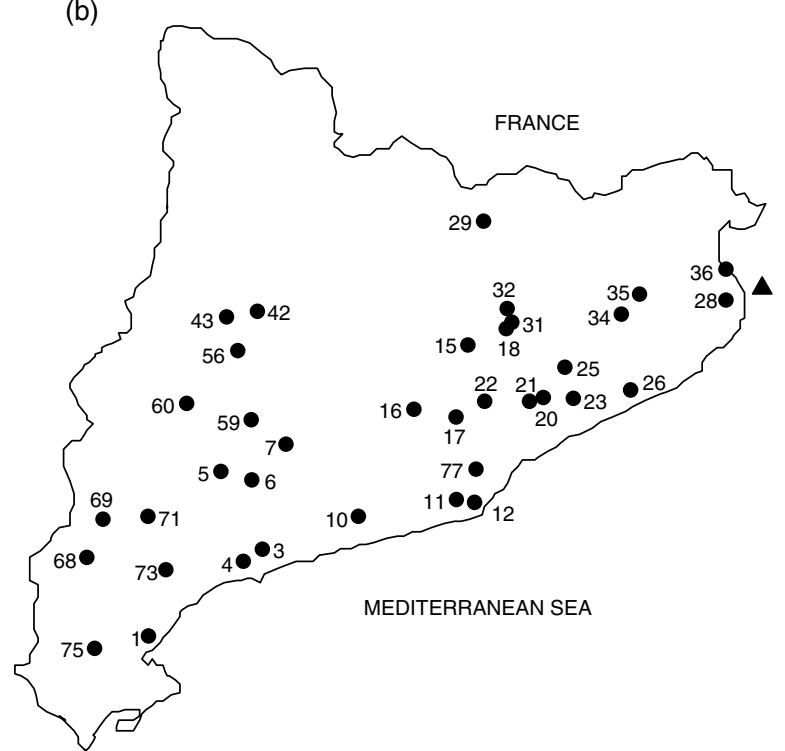

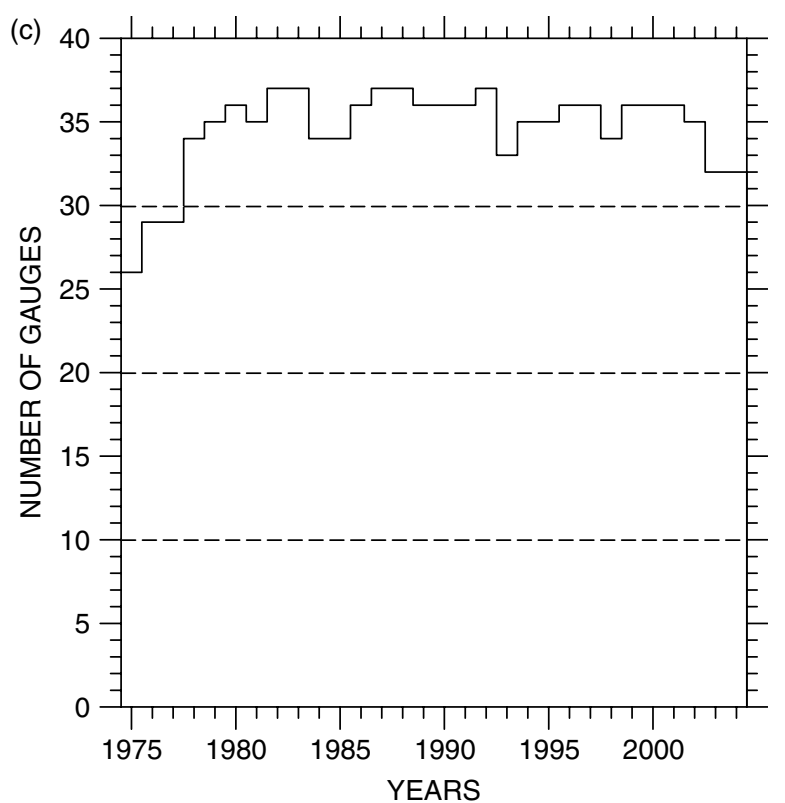

Figure 1. (a) Main orographic features of Catalonia. (b) Location of the 37 stations. L'Estartit station on the Mediterranean continental shelf is indicated by a black triangle. (c) Number of available stations for every year of the recording period.

always exceeds daily $T_{\min }$. Fourth the temporal coherency is tested by checking if consecutive temperature records differ by more than a number of degrees. The last procedure checks the spatial coherency. Differences between a daily temperature record and the average value obtained from the whole network for the same day should not exceed a number of standard deviations, which is also derived from the whole network data.

Daily records exceeding (lowering) $50(-50)^{\circ} \mathrm{C}$ are assumed as wrong and more than four consecutive days with the same maximum (minimum) temperature and daily temperatures exceeding thresholds of four standard deviations are considered suspicious of recording errors. Additionally, consecutive records differing by more than $25^{\circ} \mathrm{C}$ are discarded. Except for some specific daily records, which have been checked in detail and finally accepted, the rest of incidences on the checking process are assimilated to missing daily data.

Gross errors detected by the first procedure are null. Incidences detected by the internal consistence tests are null for most of the stations; however, for a few temperature series they exceed $0.1 \%$ of record lengths. Checking of consecutive daily records with exactly the same temperature indicates a relatively high number of incidences (close to $1 \%$ of record lengths) for a few stations, possibly due to poor precision when reading thermometer scales. The other tolerance test depicts a ratio of incidences very close to $0.5 \%$ for most of the records. Even though a threshold level of four standard deviations could suggest unlikely records, significant departures from averages along the recording years for a calendar day cannot be discarded. Such departures 
have been also analyzed by means of the Crossing Theory, generating outstanding hot and cold events (Lana et al., in press). With respect to the temporal coherency, consecutive daily records with differences exceeding $25^{\circ} \mathrm{C}$ are very unlikely and they can be due to wrong temperature recording or other inappropriate data management. The ratio of incidences does not exceed $0.2 \%$, and sometimes is lower than $0.1 \%$, except for station 69 , which is characterized by $2 \%$ of daily records not passing this checking process. Finally, the constraint of spatial coherency is accomplished quite well for all series. While most of them present a null ratio of incidences, a few series depict very low ratios from 0.01 to $0.1 \%$. As a summary, 784327 records have been checked and 8691 daily incidences detected $(1.1 \%$ of records).

\section{Homogeneity tests and results}

Four tests are applied to detect possible departures from homogeneity of temperature series: the standard normal homogeneity test (SNHT) (Alexandersson, 1986; Alexandersson and Moberg, 1997; Tomozeiu et al., 2002; Brunet et al., 2007b; Kyselý and Domonkos, 2006), the Buishand range (Buishand, 1982) and the Pettitt (Pettitt, 1979; Tarhule and Woo, 1998; Gilles et al., 2006; Kyselý and Domonkos, 2006; Kyung-Ja et al., 2006) tests and the Von Neumann ratio test (VNRT) (Von Neumann, 1941; Mitchell et al., 1966; Serra et al., 2001). All of them take as null hypothesis that the elements of the temperature series are independent and identically distributed. For the first three tests, the alternative hypothesis leads to accepting the existence of breaks in the series, thus permitting to detect when these breaks are more likely. The alternative hypothesis for the VNRT establishes a significance percentage for a lack of randomness of the series, which could be a sign of significant time trends. A detailed discussion of these four tests can be found in Wijngaard et al. (2003). It is interesting to remark that, whereas the SNHT detects more easily breaks at the beginning and the end of the series, the Buishand range and the Pettitt tests are more sensitive to breaks in the middle. The VNRT assess the randomness of the series, but it is not able to detect breaking points. These four tests are indicated by Aguilar et al. (2003) as a valid approach to assess the homogeneity of daily time series. The same authors conclude that homogeneity adjustments of daily data are questionable and they recommend excluding daily data from the analysis when lack of homogeneity is detected. Nevertheless, some controversy exists around this question. For instance, Brunet et al. (2008) show a few examples of homogeneity adjustments based on interpolation of monthly adjustment factors on a daily timescale, according to the schema proposed by Vincent et al. (2002).

While the SNHT, the Buishand range and the Pettitt tests of homogeneity have been applied to the 37 series of annual average of daily $T_{\max }$ and $T_{\min }$, the VNRT has been applied to residuals of monthly average of $T_{\max }$ and $T_{\min }$. In this manner, annual and seasonal periodicities are removed for an easier interpretation of departures from the assumption of homogeneity and randomness.

Table III lists the years for which a break is detected in each series by the first three tests. Bold characters indicate the breaking year finally assumed. It is worth mentioning that there is often an agreement in the breaking year detected by the three tests. When two out of three tests detect the same year, this is assumed as the breaking year. There are only a few series for which the three tests indicate different years, the discrepancies being not greater than 2 years.

A very relevant fact is that most of breaks for annual $T_{\max }$ and $T_{\min }$ are detected for the years 1984-1986 and 1992-1994, which could be linked to two global time trend changes manifested around 1984 and 1992, as mentioned in the Introduction. A natural cause of these common breaking years is the volcanic eruptions of El Chichón, Mexico, in March and April 1982, and Mount Pinatubo, Philippines, in June 1991. Both eruptions reached the stratosphere, injecting high amounts of $\mathrm{SO}_{2}$ (Robock, 2000; Dunn, 2004), causing a reduction in solar radiation at the surface (decrease in temperatures) and changes in circulation patterns (relative mild winters in the Northern Hemisphere) up to 2 years after the eruption (Parker et al., 1996). Moreover, although breaks caused by changes in observational procedures, instrumentation or station location should not be discarded, it seems very unlikely that such wrong data treatment occurred at the same time for most of the thermometers. The magnitude of the temperature discrepancies at the detected breakpoints is quantified in order to validate or reject the series. The discrepancies evaluated by extrapolation of time trends before and after the breaking year manifest that temperature jumps are not very relevant. However, the homogeneity of the two series (stations 5 and 16) is questionable because of the temperature jumps at their breakpoints. A common breaking year, 1990, is detected by the three tests for annual $T_{\max }$ of station 5, with a sharp temperature change of approximately $2.8^{\circ} \mathrm{C}$. For annual $T_{\min }$ of station 16 , the common breaking year is 1996 and the temperature change is around $1.2^{\circ} \mathrm{C}$. Given that the breaking years are out from the 1984-1986 and 1992-1994 ranges and that temperature jumps are large enough, both series are discarded for the forthcoming analyses. Consequently, 36 daily $T_{\max }$ and $T_{\min }$ and 35 DTR series out of 37 are considered.

The breaking points of the nondiscarded series have to be attributable to the effects of the two volcanic eruptions in 1982 and 1991. As mentioned earlier, it is unlikely that wrong data management occurs at the same time for most of the thermometers. Additionally, the temperature jumps at the breaking points are quite moderate. In consequence, some lack of homogeneity should be attributable to natural phenomena but not to instrumental or human factors. Then, remembering also the controversy around the homogeneity process at 
Table III. Years for which breaks in the temperature series are detected according to the SNHT and Buishand and Pettitt tests.

Bold characters indicate the assumed breaking year. Empty cells correspond to series without significant breaks.

\begin{tabular}{|c|c|c|c|c|c|c|c|c|}
\hline \multirow[t]{2}{*}{ CODE } & \multicolumn{4}{|c|}{$T_{\max }$} & \multicolumn{4}{|c|}{$T_{\min }$} \\
\hline & SNHT & BUIS. & PETT. & YEAR & SNHT & BUIS. & PETT. & YEAR \\
\hline 1 & 1993 & 1993 & 1993 & 1993 & 1993 & 1986 & 1986 & 1986 \\
\hline 3 & 1986 & 1987 & 1993 & 1986 & 1986 & 1986 & 1986 & 1986 \\
\hline 4 & 1993 & 1993 & 1993 & 1993 & 2002 & & & \\
\hline 5 & 1990 & 1990 & 1990 & 1990 & 1993 & 1993 & 1993 & 1993 \\
\hline 6 & 1993 & 1993 & 1993 & 1993 & 1986 & 1993 & 1993 & 1993 \\
\hline 7 & 1986 & 1986 & 1986 & 1986 & 1988 & 1988 & 1988 & 1988 \\
\hline 10 & 1996 & 1993 & 1993 & 1993 & 1999 & 1994 & 1994 & 1994 \\
\hline 11 & 1993 & 1993 & 1993 & 1993 & 1986 & 1987 & 1993 & 1986 \\
\hline 12 & & & & & 1993 & 1993 & 1993 & 1993 \\
\hline 15 & & & & & 1988 & 1988 & 1988 & 1988 \\
\hline 16 & 1981 & 1985 & 1985 & 1985 & 1996 & 1996 & 1996 & 1996 \\
\hline 17 & 1993 & 1993 & 1993 & 1993 & 1993 & 1993 & 1993 & 1993 \\
\hline 18 & 1993 & 1993 & 1993 & 1993 & 1986 & 1986 & 1986 & 1986 \\
\hline 20 & 1994 & 1994 & 1994 & 1994 & 1993 & 1993 & 1993 & 1993 \\
\hline 21 & 1993 & 1993 & 1993 & 1993 & 1986 & 1986 & 1986 & 1986 \\
\hline 22 & 1980 & 1993 & 1993 & 1993 & 1985 & 1986 & 1986 & 1986 \\
\hline 23 & & & & & 1986 & 1986 & 1988 & 1986 \\
\hline 25 & & & & & 1980 & & & \\
\hline 26 & & & & & 1986 & 1986 & 1986 & 1986 \\
\hline 28 & 1984 & 1984 & 1984 & 1984 & 1979 & 1990 & 1994 & \\
\hline 29 & 1980 & 1982 & 1982 & 1982 & & & & \\
\hline 31 & 1980 & 1984 & 1984 & 1984 & 1985 & 1985 & 1986 & 1985 \\
\hline 32 & 1986 & 1987 & 1986 & 1986 & 1979 & & & \\
\hline 34 & 1993 & 1993 & 1993 & 1993 & 1981 & 1985 & 1985 & 1985 \\
\hline 35 & 1980 & 1984 & 1984 & 1984 & 1986 & 1986 & 1987 & 1986 \\
\hline 36 & 1987 & 1987 & 1992 & 1987 & 1980 & 1985 & 1987 & 1985 \\
\hline 42 & 1993 & 1993 & 1993 & 1993 & 1983 & 1983 & 1983 & 1983 \\
\hline 43 & & & & & 1984 & 1984 & 1984 & 1984 \\
\hline 56 & & & & & 1976 & 1986 & 1986 & 1986 \\
\hline 59 & 1982 & 1983 & 1986 & 1983 & 1982 & 1985 & 1986 & 1986 \\
\hline 60 & 1992 & 1992 & 1992 & 1992 & 1984 & 1984 & 1985 & 1984 \\
\hline 68 & & & & & & & & \\
\hline 69 & 1993 & 1993 & 1993 & 1993 & & & & \\
\hline 71 & 1992 & 1992 & 1992 & 1992 & 1978 & & & \\
\hline 73 & 1989 & 1989 & 1989 & 1989 & & & & \\
\hline 75 & 1993 & 1993 & 1993 & 1993 & 1993 & 1993 & 1993 & 1993 \\
\hline 77 & 1993 & 1993 & 1993 & 1993 & 1985 & 1985 & 1985 & 1985 \\
\hline
\end{tabular}

daily scale, selected daily series are used for the forthcoming process without any additional treatment. Obviously, natural phenomena and increasing GHG effects could jointly contribute to time trends on $T_{\max }$ and $T_{\min }$.

Figure 2 shows some examples of annual average $T_{\max }$ and $T_{\min }$ (stations 4, 12, 22 and 75). Straight lines depict time trends. For station 4, a sharp increase in $T_{\max }$ is observed in 1993 and no relevant change is observed in $T_{\min }$. The reverse situation is observed for station 12. This lack of sharp changes is in agreement with no breaking years detected by the homogeneity tests. Series of station 22 are characterized by smooth decrease $\left(T_{\max }\right)$ and increase $\left(T_{\min }\right)$ of the time trends that are coincident with the respective breaking years detected by the tests. Finally, sharp increases are observed for both series of station 75 for the same breaking year, in agreement with that detected by the three homogeneity tests. The increment is remarkable for $T_{\max }$ and moderate for $T_{\min }$, and time trends are small.

Figure 3 illustrates the application of the VNRT to the series of monthly residuals of $T_{\max }$ and $T_{\min }$ of the same stations as Figure 2. It is observed that the empirical statistics (thick and thin solid line respectively) depart from the 95\% confidence level bands (dashed lines) around 1980. The nonrandomness of these series has to be accepted then with a probability of at least $95 \%$. It is worth mentioning that the rest of the stations show a similar behavior. Owing to the persistence of the departure of the statistic from the confidence bands, it cannot be discarded that the lack of randomness of the temperature series could be attributable to relevant time trends. This aspect is exhaustively investigated in the next section. 

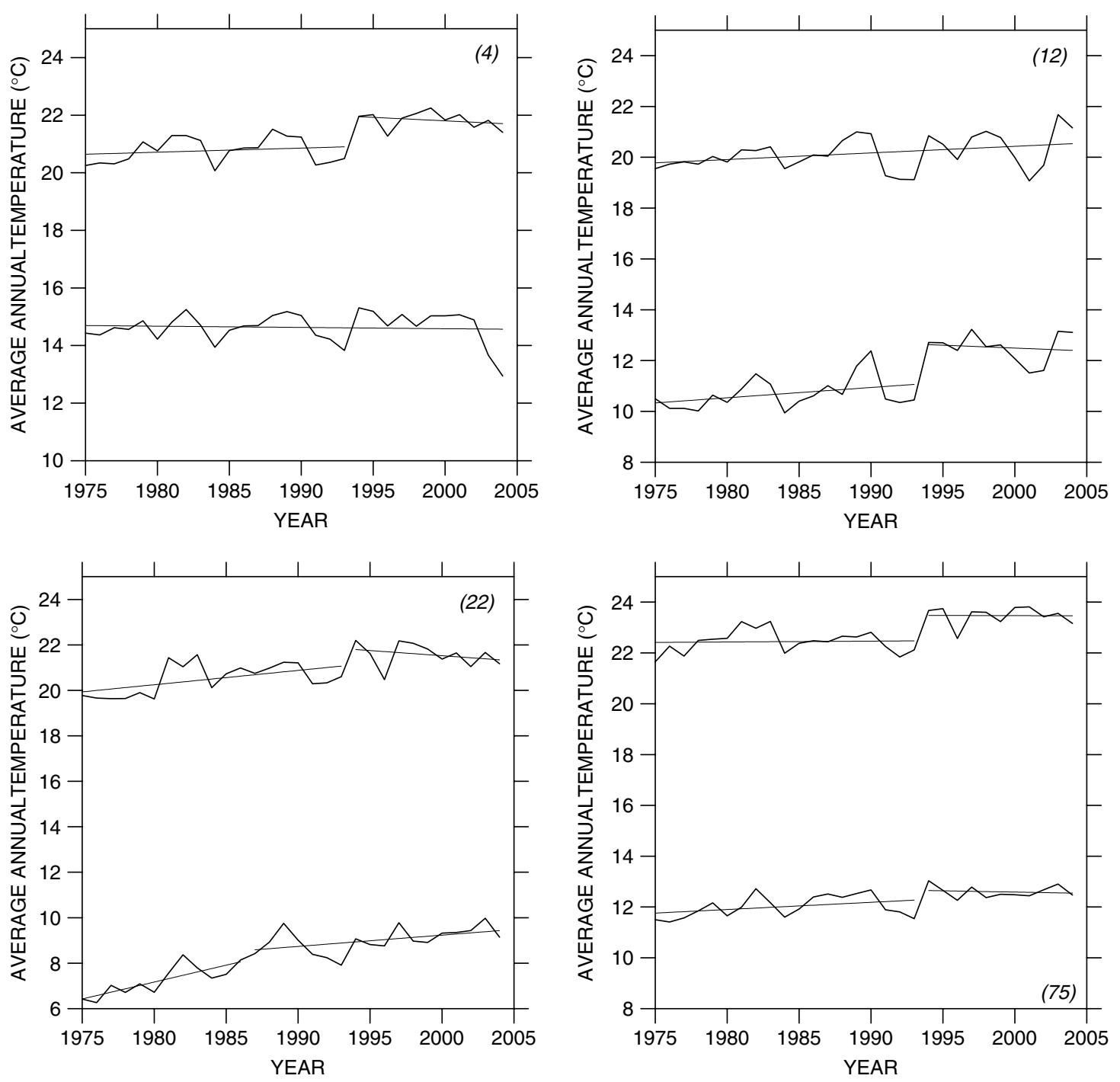

Figure 2. Series of annual average $T_{\max }$ and $T_{\min }$ for stations 4, 12, 22 and 75. Straight lines depict time trends evaluated before and after the breaking years.

\section{Temperature time trends}

\subsection{Methodology}

Time trends in $T_{\max }, T_{\min }$ and DTR are extensively studied at daily scale. By assuming that, in contrast with volcanic eruptions that could generate short-term effects along a few years, the possible effects on temperatures due to GHG increase are of long-term and continuous nature; however, the estimation of time trends by linear regression might not be a sufficiently robust method. The main reason would be the time irregularity of the series, generated by the superposition of short- and long-continuous components. For all these reasons, the estimation of time trends has been complemented by the most robust Kendall-tau procedure. Owing to the statistical treatment, this procedure favors underlying long-term trends in front of accompanying short-term trends. If a relevant discrepancy exists between both methods, the calendar day trend deduced by the Kendalltau method is assumed (Sen, 1968; Kunkel et al., 1999; Zhang et al., 2004b). The statistical significance of trends is established by the Mann-Kendall and the Kendall-tau tests (Mitchell, 1966; Sneyers, 1990). Only statistically significant trends, at least at a $95 \%$ level, according to both tests are considered for the forthcoming analyses. It is worth mentioning that for most of the stations both tests are in agreement.

The field significance of trends can be validated by a process based on the binomial distribution, using the signs of the local trends, and assuming the lack of field trend as null hypothesis. This assumption would imply that a half of the stations would be associated with positive trends and the other half with negative, with equal probabilities $u=v=1 / 2$. If $\ell$ series out of $\ell_{0}$ are governed by positive (negative) local trends, the corresponding probability, based on the binomial distribution, is

$$
P\left(\ell \leq \ell_{0}\right)=\sum_{j=0}^{\ell} \frac{\ell_{0} !}{j !\left(\ell_{0}-j\right) !} u^{j} v^{\ell_{0}-j}
$$



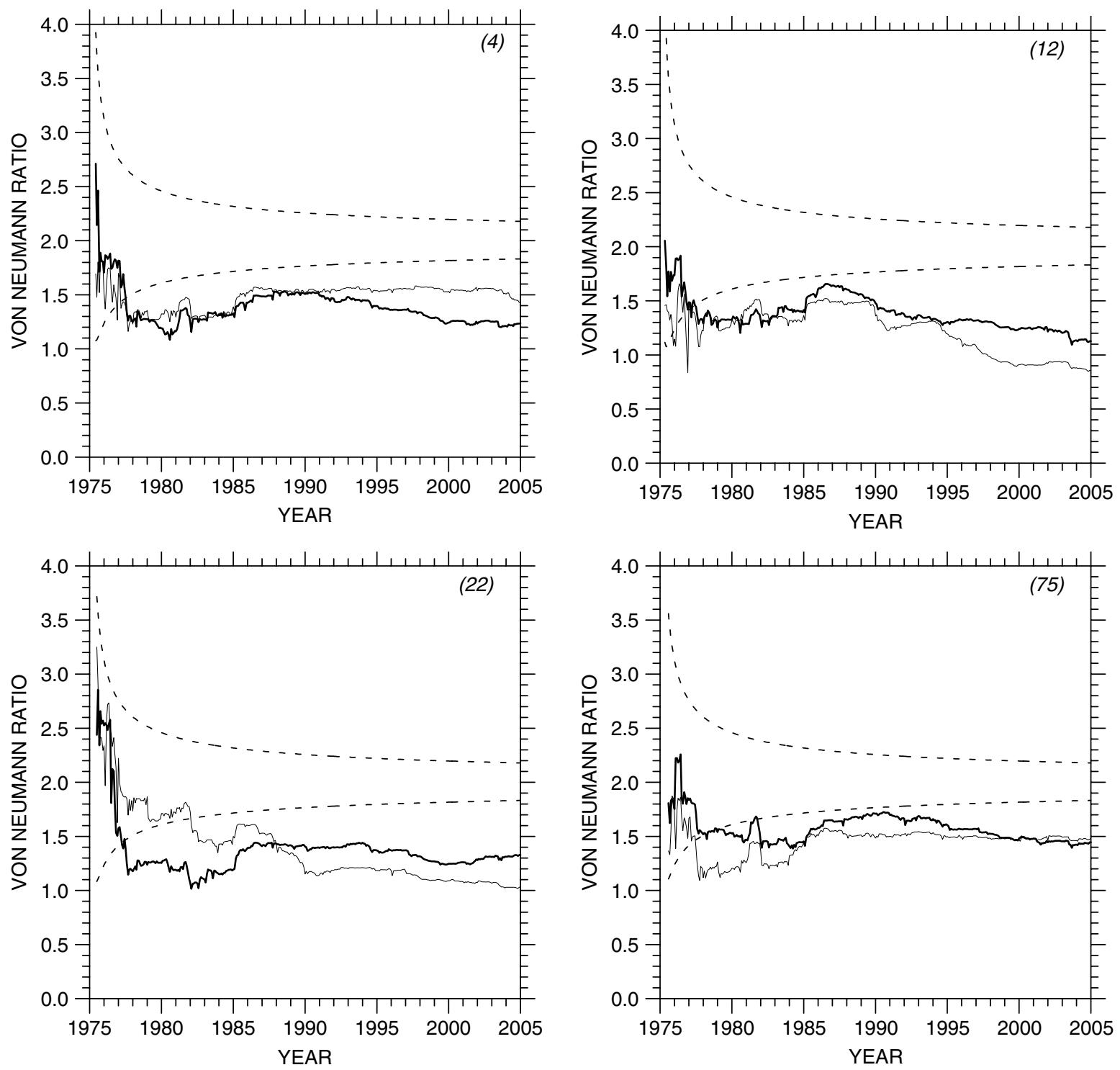

Figure 3. Examples of the VNRT applied to monthly residuals of $T_{\max }$ (thick line) and $T_{\min }$ (thin line) for the same stations as Figure 2. Dashed lines represent $95 \%$ confidence bands.

Similar to the criteria used in the Mann-Kendall and Kendall-tau tests, a field trend is assumed to be significant at the $95 \%$ level if $1-P\left(\ell \leq \ell_{0}\right)$ equals or exceeds 0.95 .

\subsection{Significant trends of $T_{\max }, T_{\min }$ and DTR}

Figure 4 offers a spatial description of temperature time trends. The annual trend for every station, in degrees centigrade per decade, is estimated as an average of all statistically significant calendar day trends. Table IV lists the number of calendar days with significant positive or negative trends of $T_{\max }, T_{\min }$ and DTR for every station. Stations can be classified in three ranges $(<49,50-99$ and $>100$ ) of calendar days with significant trends. For $T_{\max }, 12$ stations belong to the first range, 18 to the second and just three have 100, 103 and 128 days with significant trend. For $T_{\min }$, the classification is similar to that of $T_{\max }(10,16$ and 6 respectively). A single station has an outstanding number of 156 days with significant trend (155 positive and 1 negative) along the year. This high number implies a very persistent positive trend for this station. It should be also mentioned that two stations (31 and 32) have a null number of days with significant trend, both for $T_{\max }$ and $T_{\min }$. The classification for DTR is also quite similar, with 18 , 11 and 4 stations for the three ranges. Two stations with 203 (201 negatives and 2 positives) and 238 (237 negatives and 1 positive) significant trends are also worth mentioning. Very persistent negative trends in DTR are then detected along the year for these stations.

Almost all annual average temperature trends are positive, except for seven $\left(T_{\max }\right)$ and five $\left(T_{\min }\right)$ station locations. Positive trends often exceed $1.0^{\circ} \mathrm{C} /$ decade, while negative trends are more moderate (mostly up to $-1.0^{\circ} \mathrm{C} /$ decade). The results point then to a generalized increase in daily $T_{\max }$ and $T_{\min }$. This increase is confirmed by the validation of the field significance in terms of the binomial distribution. Twenty-nine out of 36 stations with positive time trends confirm the existence of a 

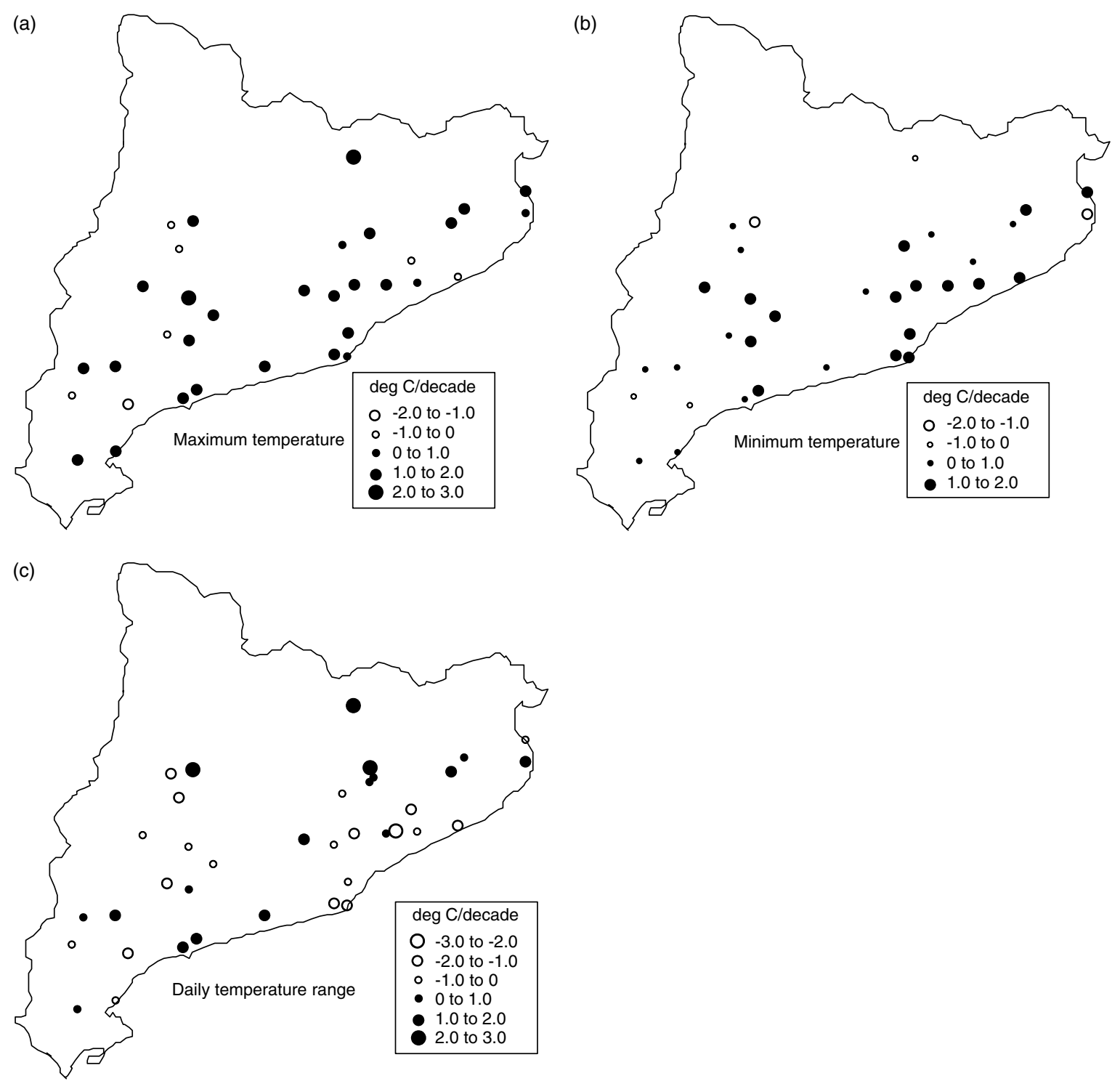

Figure 4. Spatial distribution of the average of significant calendar day trends, in ${ }^{\circ} \mathrm{C} / \mathrm{dec}$ de, for: (a) $T_{\max }$, (b) $T_{\min }$ and (c) DTR.

field positive trend for $T_{\max }$ at $99.9 \%$ significance level. Similarly, 31 out of 36 series depict positive trends for $T_{\min }$ and the field significance trend also exceeds $99.9 \%$. For DTR, 16 positive and 19 negative annual average trends are obtained, most of values ranging from -1.0 to $1.0^{\circ} \mathrm{C} /$ decade. The validation process rejects a field significant trend for DTR, as 19 out of 36 stations represent a field negative trend with $63 \%$ significance level.

Figures 5 depict the distribution of average daily time trends along the year. For every calendar day, the average trend is obtained by considering all stations having a significant local trend for that day. A first relevant feature is the clear predominance of days with positive average trend for daily $T_{\max }$ and $T_{\min }$. The period from midMay $\left(T_{\max }\right)$ or mid-April $\left(T_{\min }\right)$ to mid-September is characterized by a lack of negative trends, excepting for a short period in July. The most relevant period with predominance of days with negative $T_{\max }$ trends is observed from mid-September to mid-October. Many peaks exceeding $2.0^{\circ} \mathrm{C} /$ decade appear along the year for $T_{\max }$, more sparsely for $T_{\min }$. Negative temperature trends are in general slightly more moderate, especially for $T_{\min }$, but some outstanding values are also obtained. For DTR, positive and negative trends are almost equally distributed along the first half of the year, while a clear predominance of negative trends is observed for the July-December period. Thus, the generalized increase in daily $T_{\max }$ and $T_{\min }$, also suggested by Figures 4 , results in a decreasing trend of DTR for the second half of the year. These results are also reflected in Table V, which lists the ATT of $T_{\max }, T_{\min }$ and DTR at seasonal and annual scales, computed from all significant daily trends. $T_{\max }$ and $T_{\min }$ are characterized by positive trends at annual scale $\left(0.5^{\circ} \mathrm{C} /\right.$ decade $)$ and for most of seasons, especially relevant in spring $\left(0.9^{\circ} \mathrm{C} /\right.$ decade for $T_{\max }$ and $0.8^{\circ} \mathrm{C} /$ decade for $\left.T_{\min }\right)$ and summer $\left(0.8^{\circ} \mathrm{C} /\right.$ decade for $T_{\max }$ and $0.9^{\circ} \mathrm{C} /$ decade for $\left.T_{\min }\right)$. A remarkable positive trend is also obtained for $T_{\max }$ in winter $\left(0.7^{\circ} \mathrm{C} / \mathrm{decade}\right)$. The only average negative trend is detected in autumn for $T_{\max }\left(-0.5^{\circ} \mathrm{C} / \mathrm{decade}\right)$. DTR clearly tends to decrease 
Table IV. Number of calendar days with significant positive or negative time trends of $T_{\max }, T_{\min }$ and DTR for every station.

\begin{tabular}{|c|c|c|c|c|c|c|c|c|c|}
\hline \multirow[t]{2}{*}{ Code } & \multicolumn{3}{|c|}{$T_{\max }$} & \multicolumn{3}{|c|}{$T_{\min }$} & \multicolumn{3}{|c|}{ DTR } \\
\hline & Positive & Negative & Total & Positive & Negative & Total & Positive & Negative & Total \\
\hline 1 & 39 & 11 & 50 & 67 & 9 & 76 & 9 & 73 & 82 \\
\hline 3 & 82 & 1 & 83 & 52 & 4 & 56 & 17 & 1 & 18 \\
\hline 4 & 96 & 2 & 98 & 16 & 13 & 29 & 91 & 1 & 92 \\
\hline 5 & - & - & - & 35 & 12 & 47 & - & - & - \\
\hline 6 & 98 & 2 & 100 & 67 & 6 & 73 & 26 & 12 & 38 \\
\hline 7 & 60 & 8 & 68 & 81 & 5 & 86 & 12 & 48 & 60 \\
\hline 10 & 127 & 1 & 128 & 27 & 25 & 52 & 63 & 3 & 66 \\
\hline 11 & 55 & 1 & 56 & 155 & 1 & 156 & 0 & 49 & 49 \\
\hline 12 & 35 & 3 & 38 & 148 & 1 & 149 & 0 & 127 & 127 \\
\hline 15 & 33 & 13 & 46 & 57 & 5 & 62 & 7 & 58 & 65 \\
\hline 16 & 68 & 1 & 69 & - & - & - & - & - & - \\
\hline 17 & 37 & 1 & 38 & 90 & 0 & 90 & 6 & 25 & 31 \\
\hline 18 & 61 & 2 & 63 & 48 & 10 & 58 & 21 & 15 & 36 \\
\hline 20 & 0 & 0 & 0 & 0 & 0 & 0 & 1 & 237 & 238 \\
\hline 21 & 76 & 1 & 77 & 107 & 3 & 110 & 17 & 18 & 35 \\
\hline 22 & 60 & 4 & 64 & 141 & 2 & 143 & 2 & 37 & 39 \\
\hline 23 & 25 & 9 & 34 & 58 & 1 & 59 & 3 & 51 & 54 \\
\hline 25 & 11 & 36 & 47 & 20 & 19 & 39 & 4 & 33 & 37 \\
\hline 26 & 13 & 66 & 79 & 121 & 5 & 126 & 2 & 201 & 203 \\
\hline 28 & 21 & 22 & 43 & 0 & 128 & 128 & 88 & 0 & 88 \\
\hline 29 & 37 & 3 & 40 & 9 & 23 & 32 & 25 & 2 & 27 \\
\hline 31 & 0 & 0 & 0 & 0 & 0 & 0 & 13 & 6 & 19 \\
\hline 32 & 0 & 0 & 0 & 0 & 0 & 0 & 32 & 1 & 33 \\
\hline 34 & 84 & 2 & 86 & 24 & 9 & 33 & 50 & 1 & 51 \\
\hline 35 & 56 & 4 & 60 & 48 & 5 & 53 & 14 & 17 & 31 \\
\hline 36 & 70 & 0 & 70 & 83 & 1 & 84 & 8 & 9 & 17 \\
\hline 42 & 25 & 9 & 34 & 1 & 120 & 121 & 95 & 3 & 98 \\
\hline 43 & 12 & 37 & 49 & 33 & 12 & 45 & 7 & 83 & 90 \\
\hline 56 & 10 & 42 & 52 & 59 & 13 & 72 & 10 & 115 & 125 \\
\hline 59 & 69 & 7 & 76 & 55 & 4 & 59 & 17 & 32 & 49 \\
\hline 60 & 30 & 3 & 33 & 48 & 5 & 53 & 11 & 34 & 45 \\
\hline 68 & 20 & 34 & 54 & 15 & 31 & 46 & 11 & 43 & 54 \\
\hline 69 & 31 & 4 & 35 & 27 & 14 & 41 & 18 & 13 & 31 \\
\hline 71 & 103 & 0 & 103 & 2 & 14 & 34 & 103 & 1 & 104 \\
\hline 72 & 3 & 78 & 81 & 13 & 30 & 43 & 7 & 95 & 102 \\
\hline 75 & 59 & 1 & 60 & 51 & 7 & 58 & 19 & 7 & 26 \\
\hline 77 & 43 & 1 & 44 & 96 & 0 & 96 & 5 & 16 & 21 \\
\hline
\end{tabular}

at annual scale $\left(-0.4^{\circ} \mathrm{C} /\right.$ decade $)$, in summer $\left(-0.4^{\circ} \mathrm{C} /\right.$ decade) and especially in autumn $\left(-0.9^{\circ} \mathrm{C} /\right.$ decade $)$, while very slight changes are detected for the rest of seasons.

\subsection{Spells with a relevant number of significant time} trends

A more detailed description of the distribution of time trends along the year is given by Figure 6 , where the number of stations with statistically significant trend of daily $T_{\max }, T_{\min }$ or DTR for each calendar day is represented in three different plots. It is observed that, for many days in spring and summer, a notable number of stations have positive trends for daily $T_{\max }$ and $T_{\min }$, whereas this number is more moderate in winter and autumn. In autumn, most of significant trends of daily $T_{\max }$ are negative, thus resulting in an average negative trend, as noted before. The main feature observed for DTR is the clear predominance of stations with negative trends during the summer and autumn seasons. Looking at Figure 6, it is possible to distinguish sets of consecutive calendar days, which are termed spells from now on, with a relevant number of stations with significant trends of daily $T_{\max }, T_{\min }$ or DTR. Table VI details the dates and (ATT) of these spells, including the number of days, NST, surpassing $95 \%$ field significance. Two spells of $T_{\max }$ have five and six consecutive days with very likely field significances, sometimes exceeding $99.9 \%$. Spells of $T_{\min }$, and especially DTR, have a lower number of days with field significance. Thus, from this point of view, some of the spells detected for $T_{\max }$ would be more relevant and with more spatial coverage than those corresponding to $T_{\min }$ and DTR.

Figure 7 gives a spatial description of the spells, as they depict, for each station, the ATT and the number of days within the spell with significant trends. Four spells are distinguished for daily $T_{\max }$ (Table VI). The 

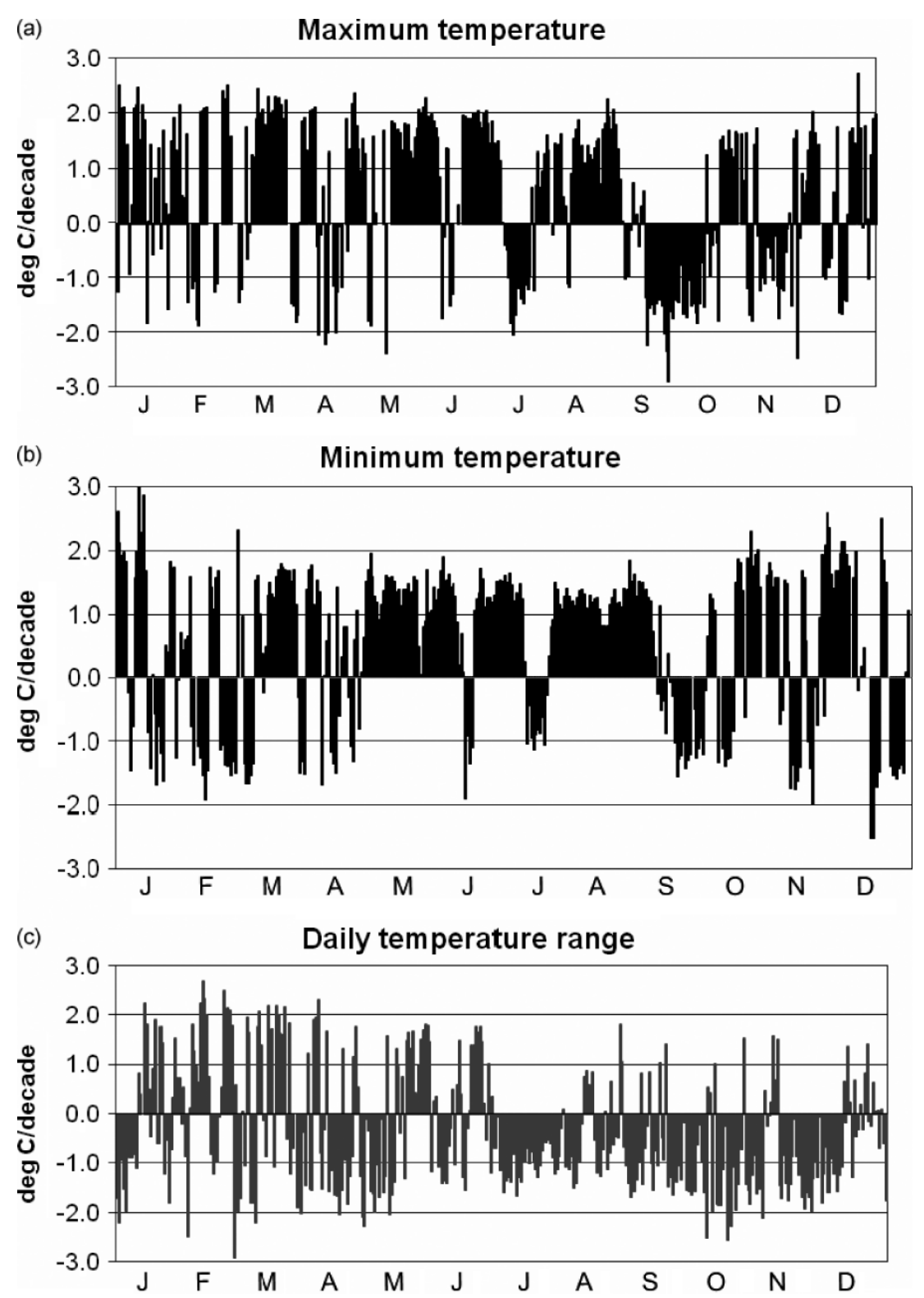

Figure 5. Time trends along the year for: (a) daily $T_{\max }$, (b) daily $T_{\min }$ and (c) DTR.

Table V. Average seasonal and annual time trends, in ${ }^{\circ} \mathrm{C} /$ decade, computed considering all significant daily trends for every station.

\begin{tabular}{lrrrrr}
\hline & $\begin{array}{c}\text { Winter } \\
\text { (DJF) }\end{array}$ & $\begin{array}{c}\text { Spring } \\
\text { (MAM) }\end{array}$ & $\begin{array}{c}\text { Summer } \\
\text { (JJA) }\end{array}$ & $\begin{array}{c}\text { Autumn } \\
\text { (SON) }\end{array}$ & Annual \\
\hline$T_{\max }$ & 0.69 & 0.88 & 0.79 & -0.45 & 0.46 \\
$T_{\min }$ & 0.09 & 0.76 & 0.89 & 0.30 & 0.51 \\
DTR & -0.01 & -0.04 & -0.41 & -0.93 & -0.36 \\
\hline
\end{tabular}

first two spells (March 12-23 and May 13-June 3), in spring, of 12 and 22 days' duration respectively, are characterized by average trends of 2.12 and $1.88^{\circ} \mathrm{C} /$ decade. Figure $7 \mathrm{a}$ and $7 \mathrm{~b}$ shows that, for many stations, the number of days with significant trend is high, and average trends exceed $2.0^{\circ} \mathrm{C} /$ decade. The other two spells (June 16-30 and August 9-31), of 15 and 22 days' duration respectively, have average trends of 1.87 and $1.59^{\circ} \mathrm{C} /$ decade. Figure 7 (c) and (d) shows that the number of days with significant trend is high again for many stations, but average trends exceeding $2.0^{\circ} \mathrm{C} / \mathrm{dec}$ ade are sparser than in the previous two spells, especially in the fourth. The relevant increasing trend of daily $T_{\max }$, detected before in spring and summer (Table V), is especially manifested at the start and the end of both seasons according to Figure 6a. For all the spells, the highest trends are mostly reached in nonlittoral sites. Conversely, more moderate values are usually detected in littoral s. The vicinity to the Mediterranean Sea would then smoothen the effects of the global warming in daily $T_{\max }$. The spatial distribution of spell lengths at a different $s$ is, however, heterogeneous and a single pattern cannot be identified.

Five spells are distinguished for daily $T_{\min }$ (Table VI). Although the first spell (February 5-11) is quite short (seven days' duration), it is worthy of mention because 


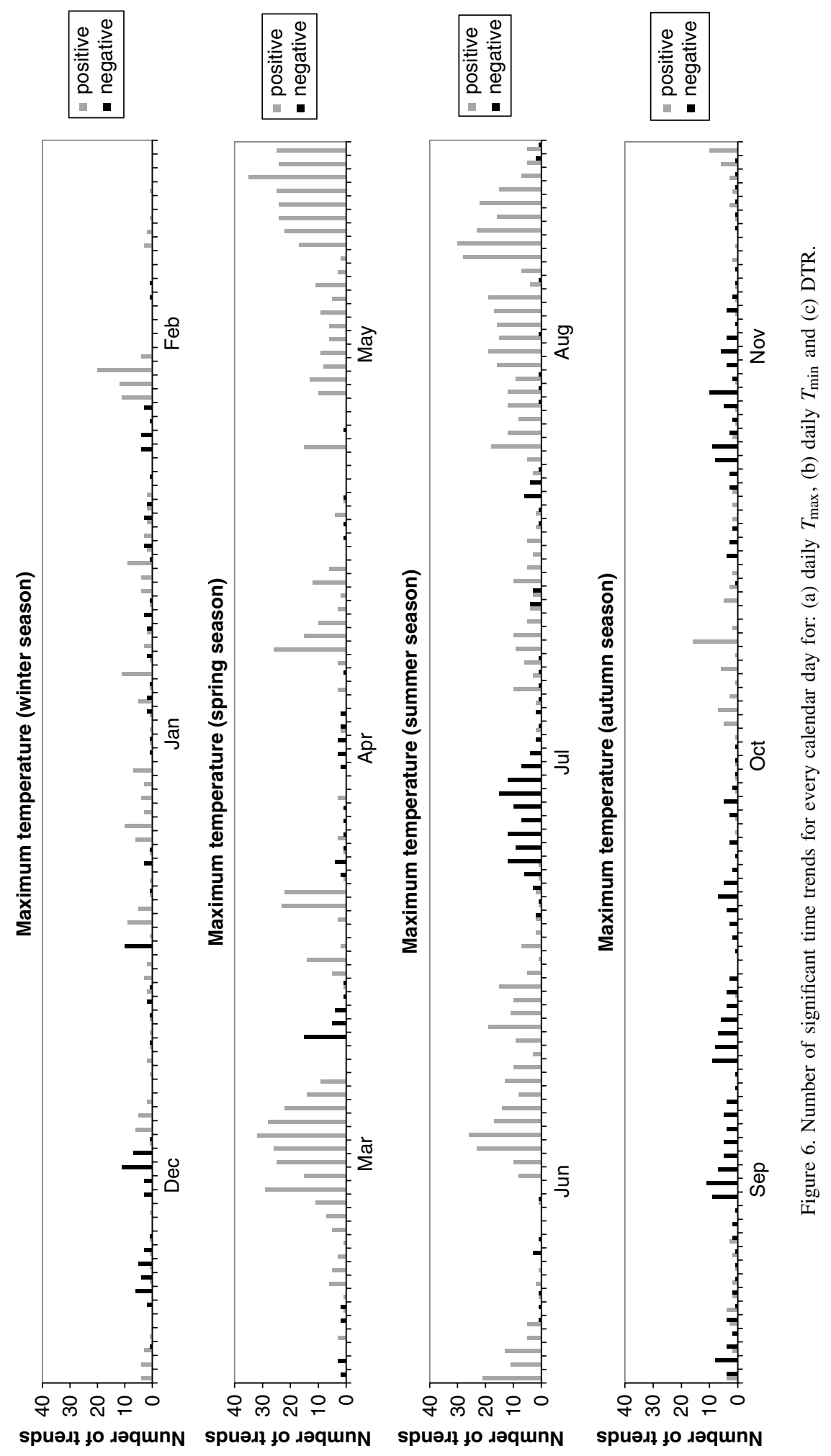




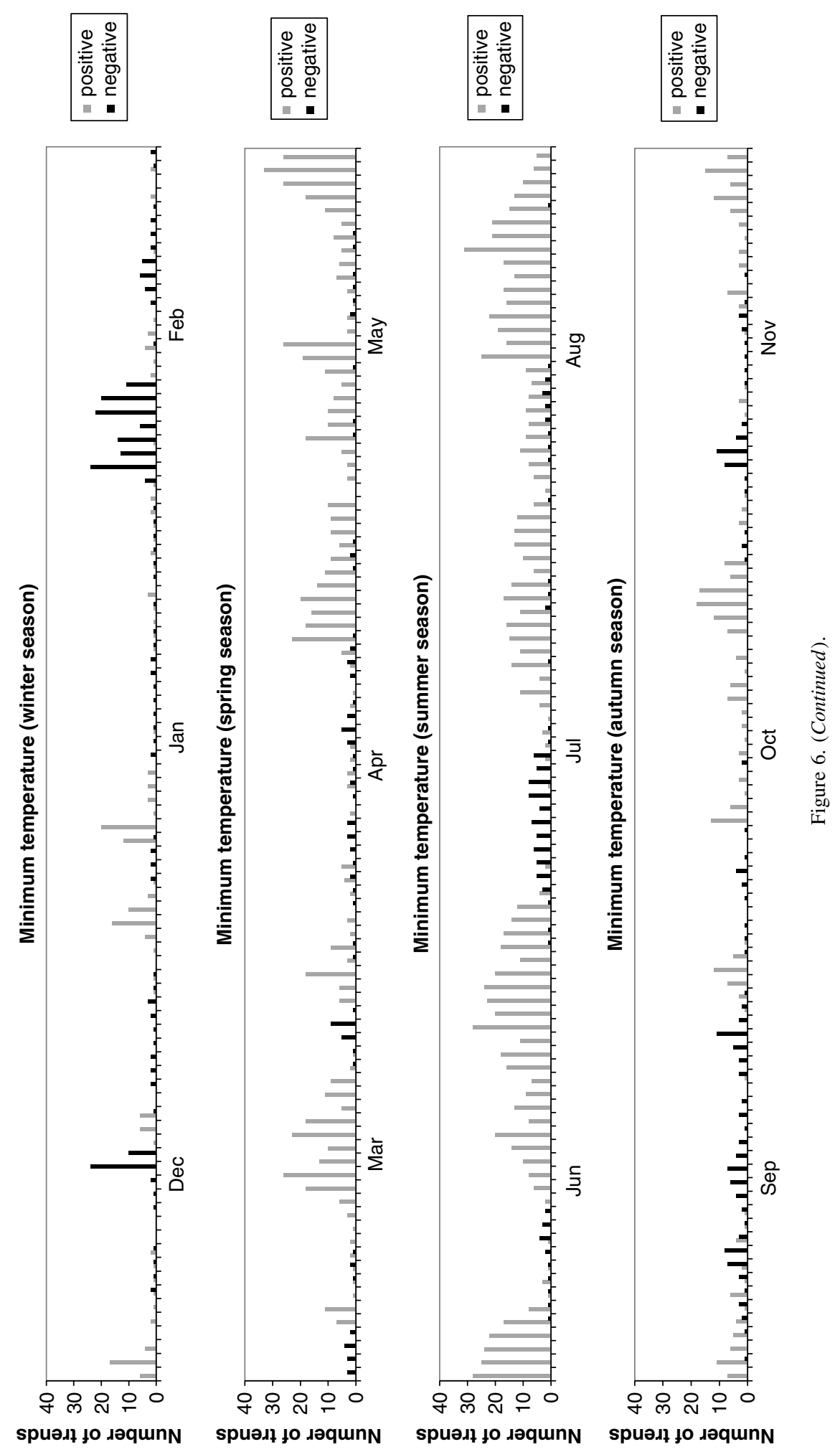




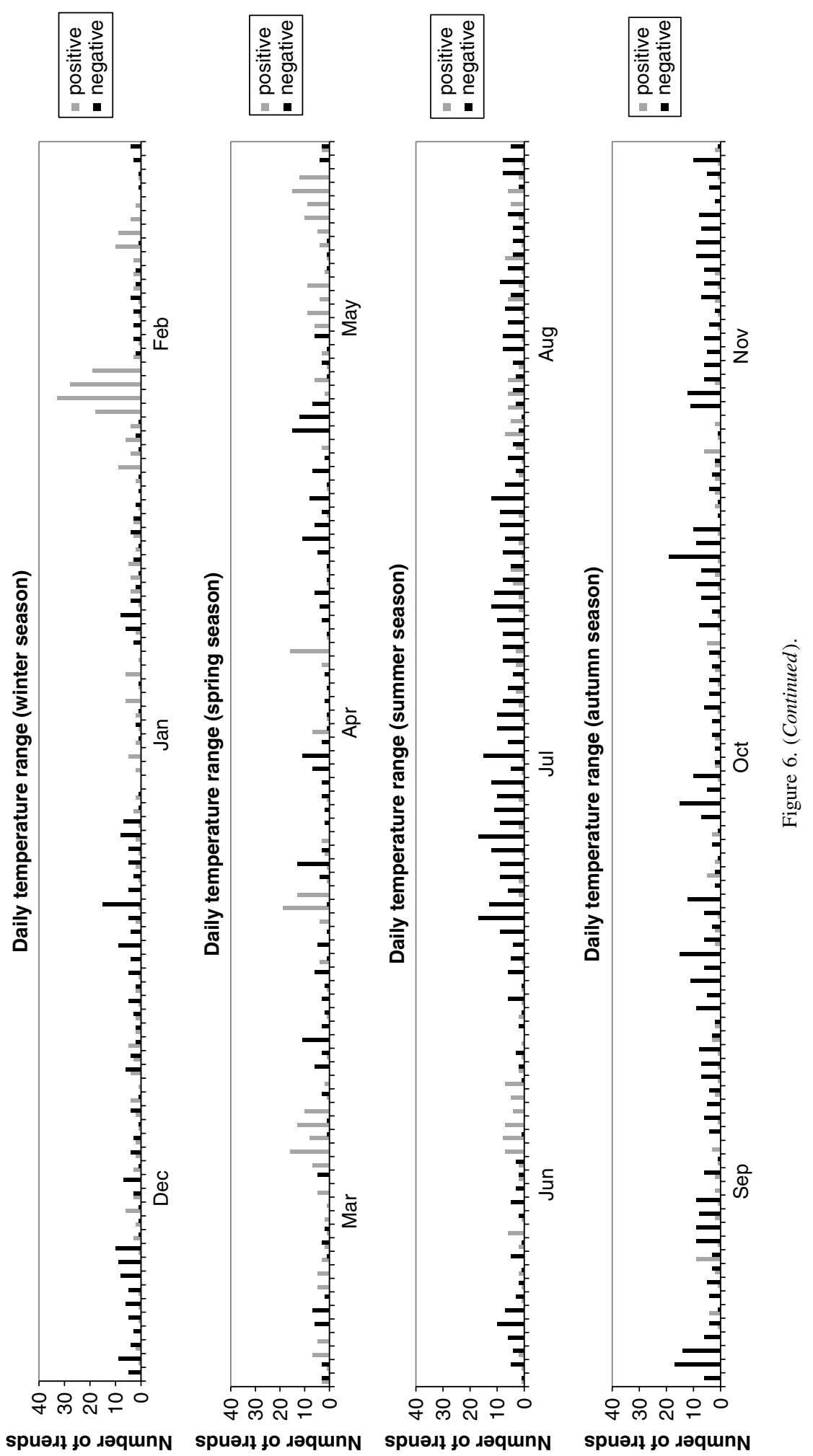


Table VI. Spells along the year for which a relevant number of stations have significant daily trends of $T_{\max }, T_{\min }$ or DTR and their average time trends, ATT, in ${ }^{\circ} \mathrm{C} / \mathrm{decade}$. The number of days with field significant trends, NST, is also indicated for every spell.

\begin{tabular}{|c|c|c|c|c|c|c|c|c|}
\hline \multicolumn{3}{|l|}{$T_{\max }$} & \multicolumn{3}{|c|}{$T_{\min }$} & \multicolumn{3}{|c|}{ DTR } \\
\hline Dates & ATT & NST & Dates & ATT & NST & Dates & ATT & NST \\
\hline & - & & February $5-11$ & -1.47 & 1 & February $9-12$ & 2.35 & 0 \\
\hline March 12-23 & 2.12 & 5 & March 15-23 & 1.66 & 1 & - & - & - \\
\hline May 13-June 3 & 1.88 & 6 & April 25-June 6 & 1.38 & 0 & - & - & - \\
\hline June $16-30$ & 1.87 & 1 & June $15-$ July 7 & 1.38 & 1 & - & - & - \\
\hline August 9-31 & 1.59 & 2 & July $22-$ August 31 & 1.23 & 2 & July 1-August 6 & -0.97 & 2 \\
\hline
\end{tabular}

this is the only spell with negative temperature trends. For most of the stations, the temperature decrease exceeds $1.0^{\circ} \mathrm{C} /$ decade (Figure 8a), giving an average trend for the spell of $-1.47^{\circ} \mathrm{C} /$ decade. The rest of the spells cover almost all spring and summer seasons and are characterized by a clear predominance of positive trends of daily $T_{\min }$, as can be seen in Figure $6 \mathrm{~b}$. The average trends are $1.66,1.38,1.38$ and $1.23^{\circ} \mathrm{C} /$ decade respectively (Table VI). The number of days with significant trend and the average trend for each station are shown in Figure 8b, c, d and e, respectively. The second (March 15-23, nine days' duration) and third (April 25 - June 6,43 days' duration) spells occur in spring and are characterized by average trends exceeding $1.0^{\circ} \mathrm{C} /$ decade for almost all of stations, without a clear distinction among littoral or nonlittoral sites. The fourth (June 15-July 7, 23 days' duration) and fifth (July 22 - August 31, 41 days' duration) spells occur in summer, at similar dates as the third and fourth spells of $T_{\max }$. Except for three stations with small negative trends, the rest have positive trends, mostly exceeding $1.0^{\circ} \mathrm{C} /$ decade. Distinctions among littoral or nonlittoral sites are not clear either. Thus, vicinity to the Mediterranean Sea does not seem to be a key factor in daily $T_{\min }$ trends. The spatial distribution of the spell lengths is very heterogeneous again and, as for daily $T_{\max }$, a single pattern cannot be easily identified.

Two spells are distinguished for DTR. A very short spell (February 9-12, four days' duration), almost overlapped with that of decreasing $T_{\min }$, is identified, thus resulting in an outstanding average positive trend of $2.35^{\circ} \mathrm{C} /$ decade (Table V). Most of the stations have significant trends for three or four days, and the highest trends are mainly located in the northeast of Catalonia (Figure 9a). The second spell (July 1-August 6, 37 days' duration) is mainly characterized by negative trends, except for a few sites. No spatial pattern is identified either. The average trend is $-0.97^{\circ} \mathrm{C} /$ decade.

As a summary, the daily temperature regime of Catalonia manifests very clear signs of increasing trends, especially in spring and summer. Owing to the complex orography of Catalonia, the temperate effects of the Mediterranean Sea and the atmospheric circulation patterns in the region, spatial and temporal patterns of the temperature regime variations are quite complex. From a spatial point of view, only the temperate effect due to the vicinity to the Mediterranean Sea could smoothen partially positive trends of daily $T_{\max }$. The conclusions for the time evolution are more clear and interesting. In agreement with Figure 6(a) and 6(b) and Tables V and VI, in the future, the temperature effects of an incoming climatic change due to global warming would result in hotter springs and summers, especially at the beginning and the end of these seasons. Nevertheless, a few consecutive days within these seasons without relevant trends are also expected. Additionally, a short winter spell would be characterized by an increasing trend on DTR, due to decreasing $T_{\min }$ and lack of statistically significant trends for $T_{\max }$.

\section{Discussion}

\subsection{Physical causes}

In addition to the rapid increase in GHG (Trenberth et al., 2007), other causes are taking part in the atmospheric warming. Solar forcing on global surface temperature during last century has been analyzed recently (Scafetta and West, 2006a,b). According to these authors, its contribution represents $25-35 \%$ of the 1980-2000 global warming. At the same time, the reduction in solar dimming in favor of solar brightening in the 1980s, caused by a reduction in emissions of both scattering sulphate and absorbing black carbon aerosols is of minor order in relation to greenhouse forcing as a cause of global warming (Wild et al., 2007).

According to the investigation of the possible impacts of enhanced GHG and sulphate aerosols on extratropical cyclone activity all over the world about the year 2050, Geng and Sugi (2003) have found that the total cyclone density will decrease significantly in midlatitudes of the Northern Hemisphere during December-January-February (DJF) and June-July-August (JJA) seasons. And although weak and medium-strength cyclones decrease, the density of strong cyclones increases by more than $20 \%$ in JJA. The reasons for these changes are linked to the decrease in baroclinicity in the lower troposphere, mainly caused by the decrease in the meridional temperature gradient. Previous studies on cyclones over the North Atlantic by Knippertz et al. (2000) pointed also toward a decrease in total cyclone 
(a)

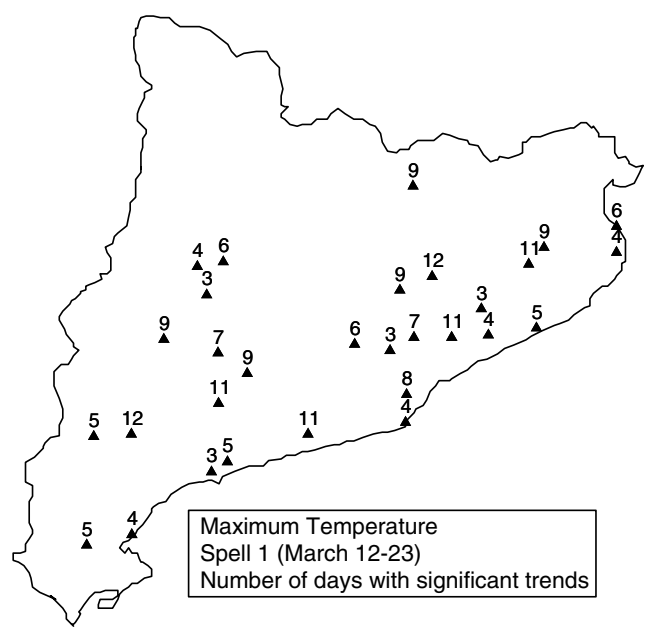

(b)
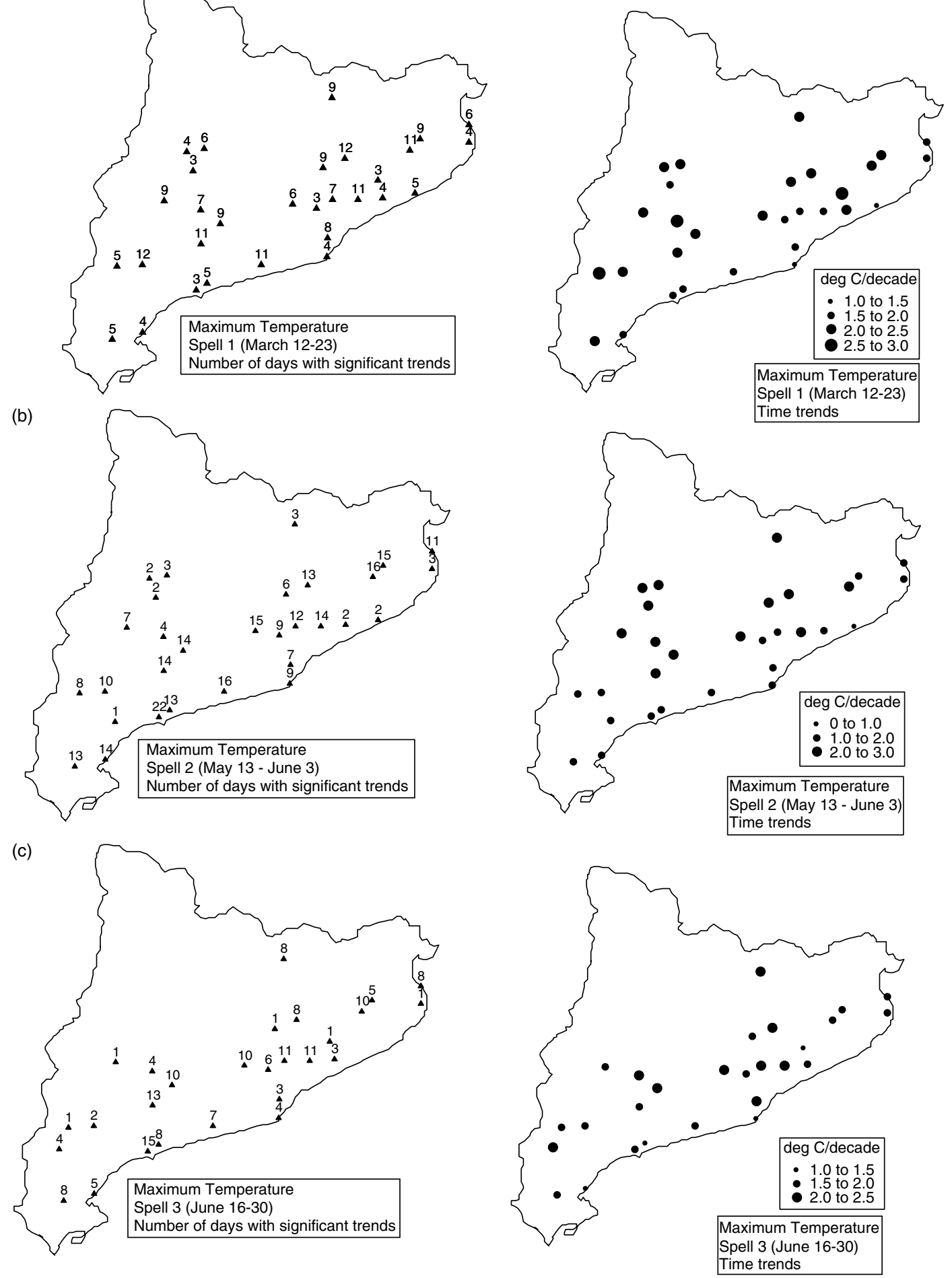

Figure 7. Number of days with significant trends and average weighted trends for the four spells of daily $T_{\max }$.

and an increase in strong cyclones, with a position shift of their tracks poleward and eastward. This shift of the storm tracks has also been found by other authors (Ulbrich and Christoph, 1999; Pinto et al., 2007). This behavior is consistent with the 1948-2002 arctic cyclone activity $\left(60^{\circ}-90^{\circ} \mathrm{N}\right)$, which shows as the number and intensity of cyclones entering the Arctic from the mid-latitudes has increased, suggesting a shift of storm tracks toward the Arctic, particularly in summer (McCabe et al., 2001;
Zhang et al, 2004a). The Mediterranean Basin would also suffer a decrease in the overall cyclonic activity, consistent with observations in the twentieth century (Lionello et al., 2006), and an increase in deep cyclones in a doubled $\mathrm{CO}_{2}$ climate scenario (Lionello et al., 2002). According to these studies, it is to suppose an increase of southwesterlies in the Iberian Peninsula, at least in winter, along the twenty-first century, with the consequent warming. In case of a year with a winter of positive 

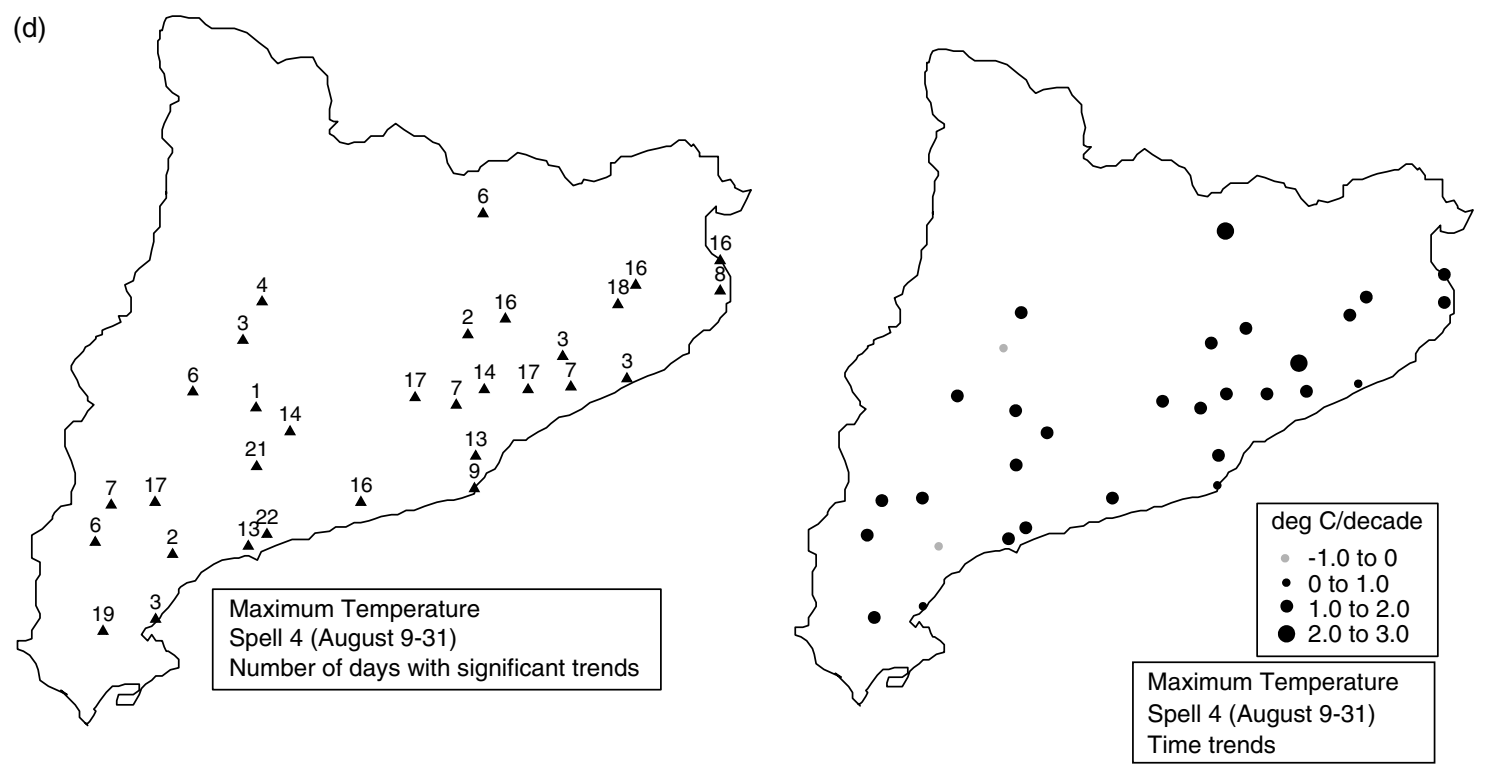

Figure 7. (Continued).

NAO index, the resultant effect would be coincident to a large degree (Otterman et al., 2002), although this oscillation keeps low correlations with the temperature in Spain in DJF months (Sáenz et al., 2001). The reduction in the overall cyclone activity in the Mediterranean would also aid in the warming in Catalonia, in agreement with patterns detected for daily $T_{\max }$ and $T_{\min }$ trends. As a second-order consequence, the observed northward shift of storm tracks supports more stable circulation conditions over Europe, manifested in a higher persistence of the atmospheric circulation in last decades, with the consequent exacerbation of impacts on the occurrence and severity of temperature extremes (Kyselý and Domonkos, 2006; Kyselý, 2007).

\subsection{Comparisons with large-scale temperature trends}

Since about 1975 up to 2004, the annual combined land surface air and sea surface temperature has increased about $0.5^{\circ} \mathrm{C}$ in the world. For latitudes larger than $20^{\circ} \mathrm{N}$, the increase has been close to $0.8^{\circ} \mathrm{C}$ (Kennedy et al., 2006). This is the largest temperature increase in a 30year period since measurements are available. In Europe, the observed increases along 1979-2005 range from -0.1 to $+0.9^{\circ} \mathrm{C} /$ decade, from the Iberian Peninsula to Scandinavia (Trenberth et al., 2007). The increase in annual $T_{\max }$ and $T_{\min }$ in Catalonia, derived from the present research, is close to $0.5^{\circ} \mathrm{C} / \mathrm{dec}$ ade. Consequently, the main patterns of time trends deduced for Catalonia are in agreement with those derived at global, hemispheric and European scales.

Attention has to be paid to these high temperature trends in just 30 years. As a reference, over the last 420000 years, the highest rate has been about $1{ }^{\circ} \mathrm{C} /$ century (Salinger, 2005). Then, if the present temperature trends keep their value along this century, such as different climatic models suggest for Europe (Räisänen et al., 2004; Sánchez et al., 2004; Kjellström, 2004), the temperature change would be certainly dangerous to living organisms (Salinger, 2005).

Evidently, DTR responds strongly to forcing from soil moisture and clouds (Dai et al., 1999; Stone and Weaver, 2002 , 2003), in such a way that it is a possible index of radiative forced climate change providing information independent of global mean temperature (Braganza et al., 2004). Dry soil conditions contribute to the amplification of the local temperature anomalies (Ferranti and Viterbo, 2006; Vautard et al., 2007). A good example could be the anomalous European hot summer of 2003, with effects enhanced by low soil moisture.

Recent studies of the twentieth century cloud cover for the two longest daily series in Catalonia shows that, in the 1975-2004 period, the cloud cover in Fabra Observatory (station 77) has an almost null linear trend and in the Tortosa Observatory (station 75) it is slightly positive (Sánchez-Lorenzo et al., 2006). Different time behavior is observed in a close Mediterranean domain as Italy. The cloud cover average trend is about -0.07 octa/decade in the period 1975-2004 (Toreti and Desiato, 2008), while annual temperature ATTs are similar to those deduced here. In a planetary scale, the global average trend of total cloud cover over land, years 1971-1996, is small $(-0.7 \% /$ decade), offsetting the small positive trend found for the ocean, and resulting in a nonsignificant trend for the land-ocean average (Warren et al., 2007).

\subsection{Comparisons with regional scale temperature} trends

As mentioned, the temperature trends obtained for Catalonia are mainly in agreement with those established by Trenberth et al. (2007) for the NE of Spain (years 1979-2005), where significant positive trends of $0.3-0.5^{\circ} \mathrm{C} /$ decade at annual scale and $0.5-0.7^{\circ} \mathrm{C} /$ decade in spring and summer are detected. Brunet et al. (2007a) also obtained a significant positive trend of $0.5^{\circ} \mathrm{C} / \mathrm{decade}$ 
(a)
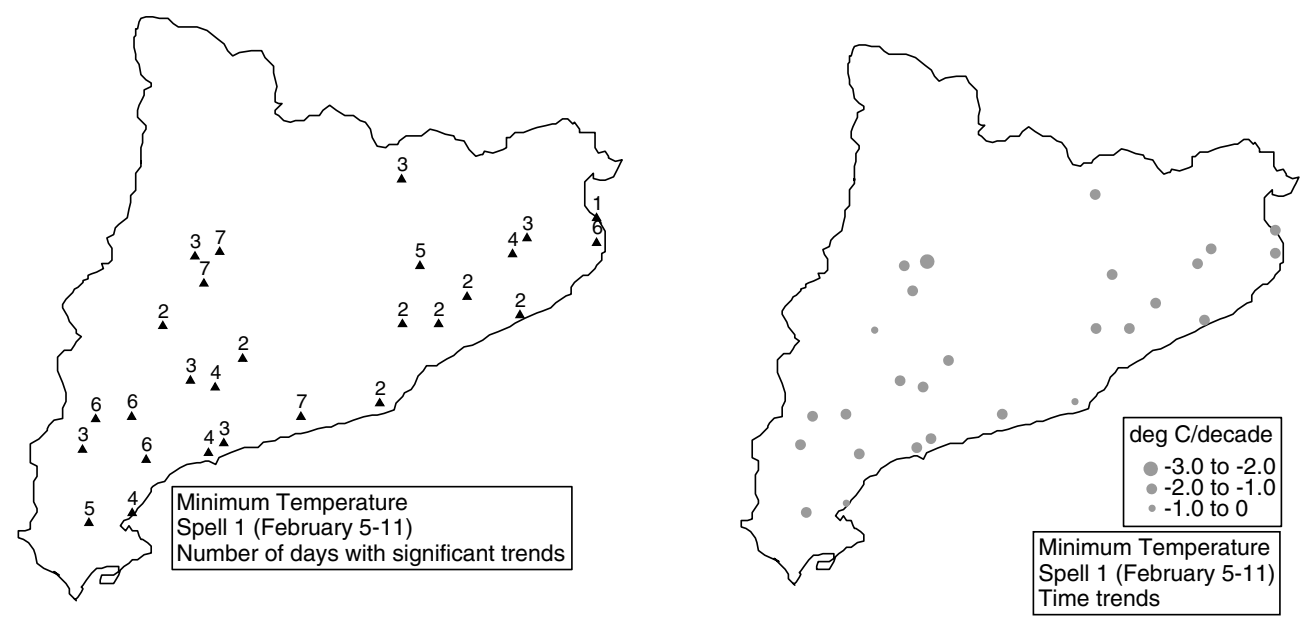

(b)
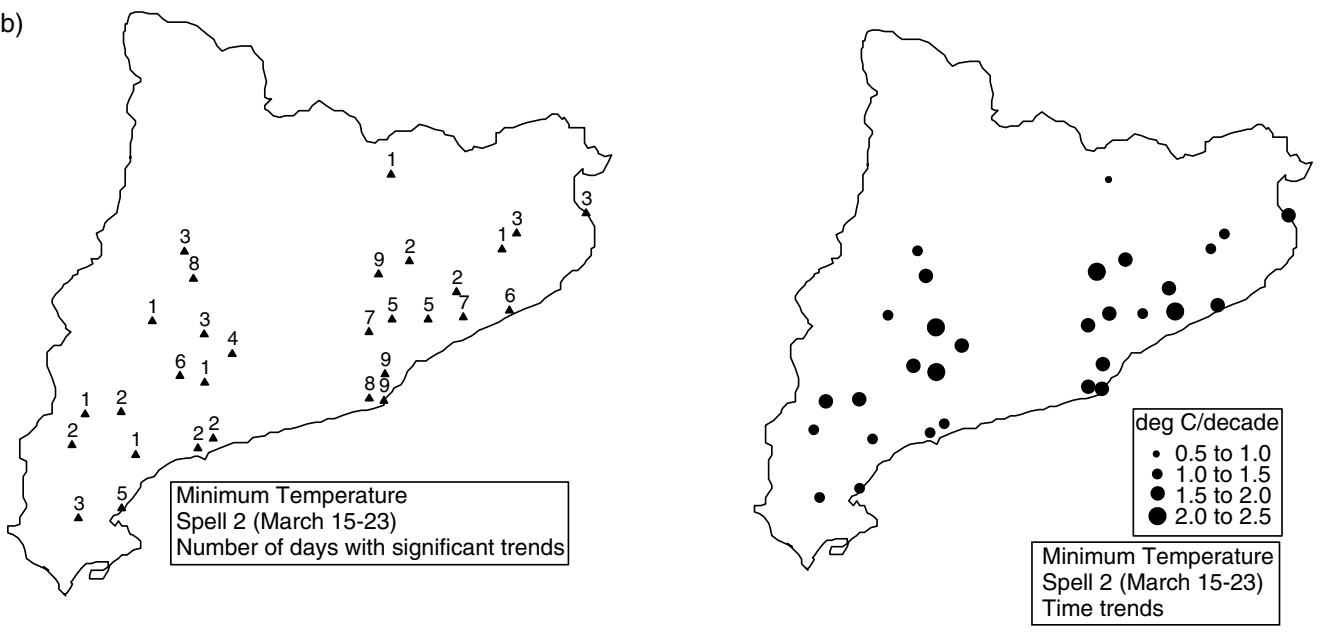

(c)
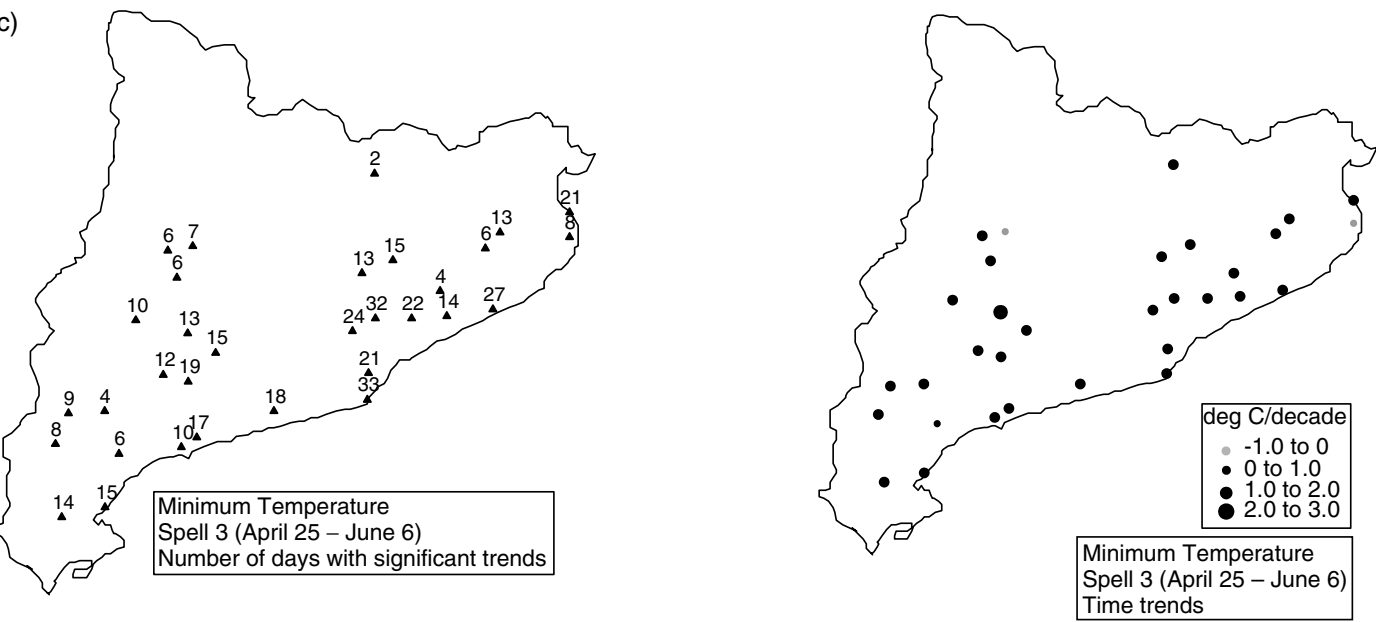

Figure 8. Number of days with significant trends and average weighted trends for the five spells of daily $T_{\min }$.

for daily $T_{\max }, T_{\min }$ and $T_{\text {mean }}$ temperature over Spain at annual scale for the period 1973-2005, with spring and summer seasons mostly contributing to this warming, as deduced for Catalonia. For a region of NW Spain, Del Río et al. (2007) also detected positive trends of mean $T_{\max }$ and $T_{\min }$ at annual scale during the period 1961-1997, with an increase in DTR, which is in contrast with that obtained for Catalonia. Positive trends are also deduced for all seasons except for autumn $\left(T_{\max }\right)$ and spring $\left(T_{\min }\right)$, but it must be mentioned that most of trends are nonsignificant. Other studies concerning temperature trends in different regions of Spain can be cited (Abaurrea et al., 2001; Brunet et al., 2001; Galán et al., 2001; Esteban-Parra et al., 2003). This warming tendency for the last 30 years is also found in other territories of the Mediterranean basin and Europe. Ben-Gai et al. (1999) found increasing trends of daily $T_{\max }$ and $T_{\min }$ in Israel during the warm season (years 1964-1994), together with 
(d)
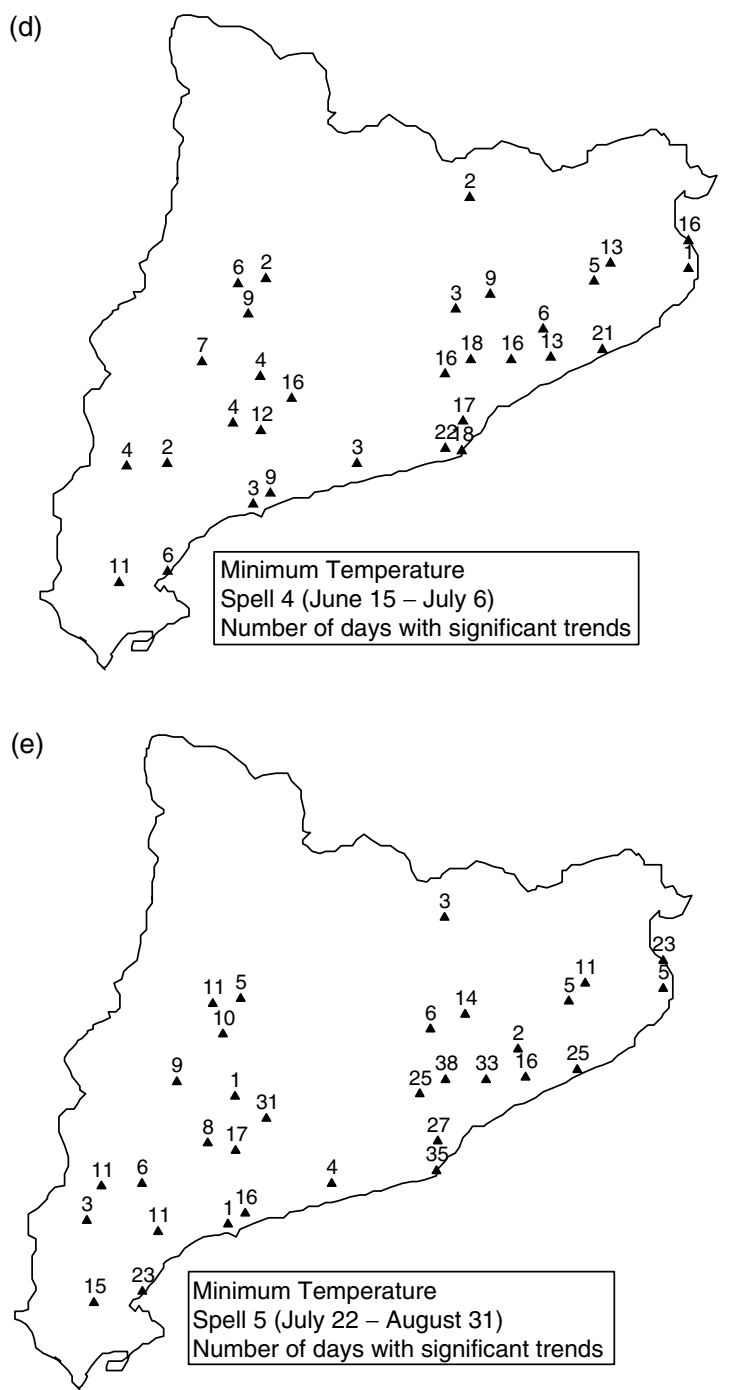
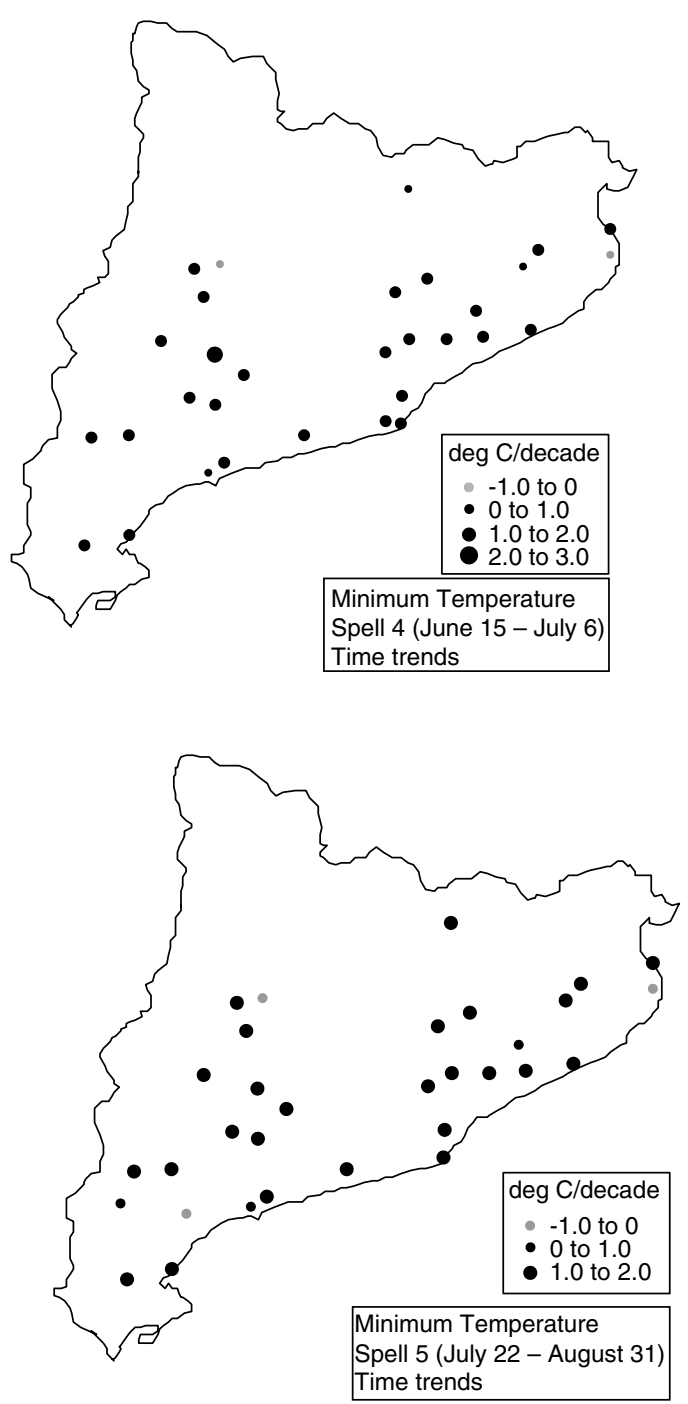

Figure 8. (Continued).

a decreasing of DTR, as deduced for Catalonia. Positive temperature trends, with an increase of DTR, are found in Italy for the period 1981-2004 (Toreti and Desiato, 2008). Rebetez and Reinhard (2008) found positive trends of monthly air temperature in Switzerland for the years 1975-2004, the greatest temperature increase occurring in spring and summer, as deduced for Catalonia.

The influence of the sea breeze on the smoothing effect of the vicinity to the Mediterranean coast on daily extreme temperature trends has to be briefly discussed. Sea breeze is a meso-scale coastal wind, which generates daily renewal and refreshing air in a wide fringe all along the Catalan coast in spring and summer months (Redaño et al., 1991). In spite of the rapid thermal rise observed in the last 30 years, the coast and a good part of inland will continue to receive the sea breeze with similar speed characteristics than before, because the temperature gradient near the land-water boundary has remained practically constant in these last 30 years. Indeed, measures of sea surface temperature, at $2.8 \mathrm{~km}$ from the northern Mediterranean coast and over a bottom depth of $85 \mathrm{~m}$ (Figure 1b), along the 1974-2005 period, have a linear trend of $0.34^{\circ} \mathrm{C} /$ decade (Vargas-Yañez et al., 2005; Salat and Pascual, 2006), which is close to the measured inland trend.

\section{Conclusions}

The detailed analysis of daily $T_{\max }, T_{\min }$ and DTR in Catalonia (years 1975-2004) manifests quite evident signs of warming, which is in agreement with numerous studies focused on global warming generated mainly by an increase in the GHG effect. Two aspects of the analysis deserve to be underlined. First, the daily scale of the series permits a detailed description of the time trends along the year, notable differences among the months and seasons of the year being detected. Second, the records of all the stations permit detecting some relevant spells along the year. Nevertheless, it has to be remembered that spell lengths and ATTs are different for every station. It should be then assumed that global warming would be manifested heterogeneously at daily 

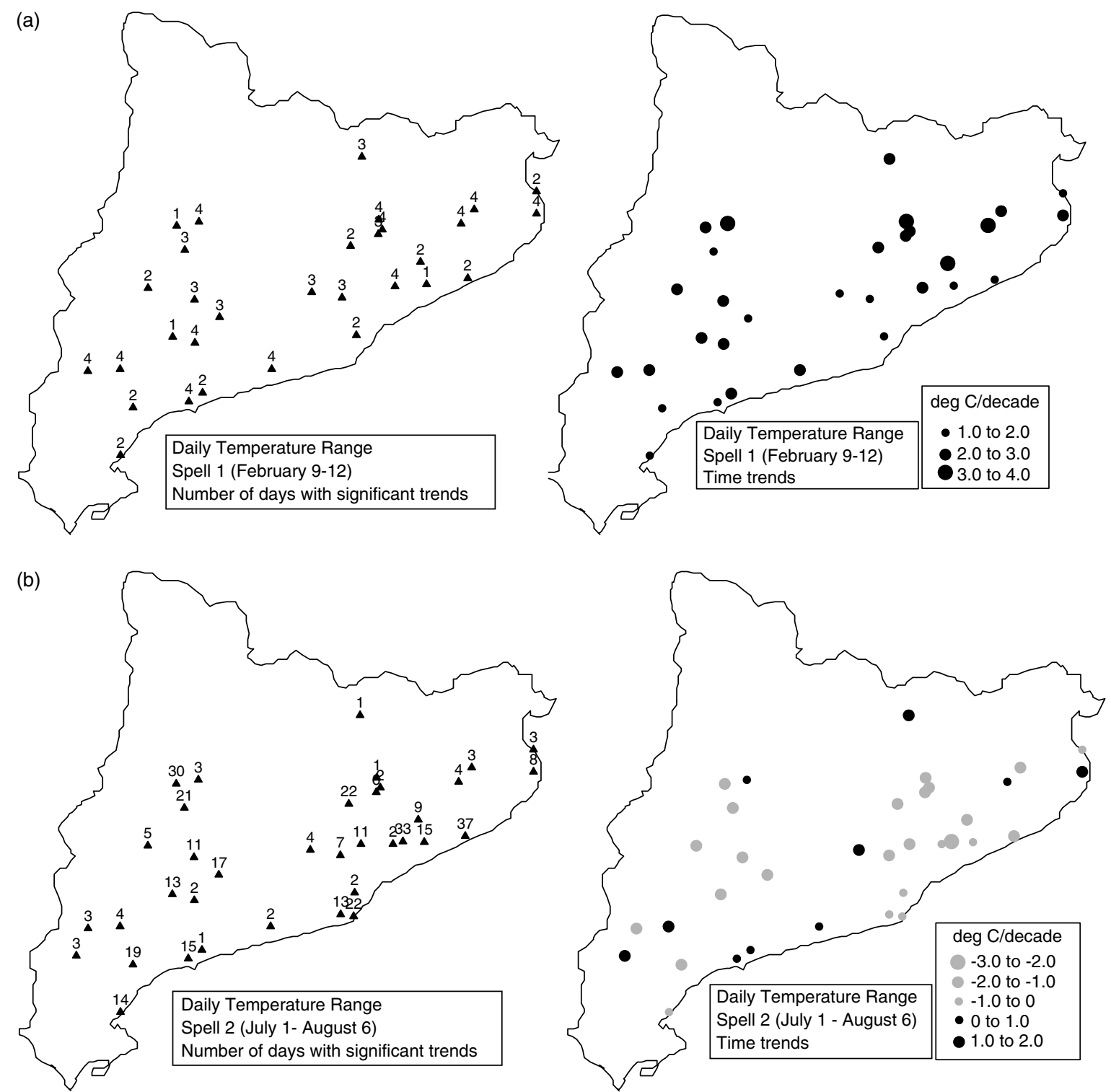

Figure 9. Number of days with significant trends and average weighted trends for the two spells of DTR.

and local scales due to the orography and the vicinity to the Mediterranean Sea.

The following are the specific features:

(1) For most of series, wrong management of daily $T_{\max }$ and $T_{\min }$ data is assumed of small relevance after the detailed application of the homogeneity tests and the comparison with years corresponding to short-period natural events (volcanic eruptions). Just two temperature series are finally rejected. Given that DTR is computed as differences between daily extreme temperatures, trends on DTR could be submitted to larger errors than those on $T_{\max }$ and $T_{\min }$, possibly due to remaining lack of homogeneity, which is difficult to remove from daily series. However, it is worth mentioning that the relevant spells with significant DTR trends are in agreement with the time evolution of $T_{\max }$ and $T_{\min }$, DTR trends also manifesting then the effects of the climatic change.
(2) Along the year, the number of significant daily positive trends exceeds that of negative trends and several months are characterized by the lack of negative trends for $T_{\min }$.

(3) Whereas a low number of average daily time trends for the different $\mathrm{s}$ are negative, positive time trends exceeding $1.5^{\circ} \mathrm{C} /$ decade are quite common, especially for daily $T_{\max }$.

(4) A uniform positive trend along the whole year must be discarded. Nevertheless, the initial and ending dates of the four $T_{\max }$ spells (positive trends) are roughly coincident with those of the $T_{\min }$ positive trend spells (Table VI). Thus, $T_{\max }$ and $T_{\min }$ spells with relevant time trends follow a quite similar calendar evolution. The most relevant feature is their notable positive trends in spring and summer.

(5) The smoothing breeze effect on temperature trends due to the vicinity to the Mediterranean Sea is especially observed for $T_{\max }$ in spring and summer. 
(6) A single short winter spell depicts negative daily $T_{\min }$ trends. However, a negative daily $T_{\max }$ trend for this short spell is not detected, thus resulting in a DTR positive trend in the same dates.

As a summary, the detailed analysis of daily $T_{\max }$, $T_{\min }$ and DTR certifies recent changes in the temperature regime in Catalonia, linked to global warming, but with relatively complex spatiotemporal patterns, and seasonal and annual temperature trends close to that indicated by Trenberth et al. (2007) for northeastern Spain. In addition, it should be stressed that the behavior at seasonal scale is an average of spells detected in Figures 6, most of them shorter than one month. Consequently, Figures 6 and their associated results could be assumed as a fine structure approach to the effects of climate change on the daily temperature regime.

\section{Acknowledgements}

The authors are indebted to the Agencia Estatal de Meteorología (Spanish Government) and the Reial Acadèmia de Ciències $i$ Arts (Barcelona), who have kindly supplied the temperature database.

\section{References}

Abaurrea J, Asín J, Erdozain O, Fernández E. 2001. Climate variability analysis of temperature series in the Medium Ebro river basin. In Detecting a Modelling Climate Change, Brunet M, López D (eds). Springer-Verlag: Berlin; 109-118.

Aguilar E, Auer I, Brunet M, Peterson TC, Wieringa J. 2003. Guidelines on Climate Metadata and Homogenization, WCDMPNo. 53, WMO-TD No. 1186. World Meteorological Organization: Geneve.

Aguilar E, Peterson TC, Ramírez Obando P, Frutos R, Retana JA, Solera M, Soley J, González García I, Araujo RM, Rosa Santos A, Valle VE, Brunet M, Aguilar L, Álvarez L, Bautista M, Castañón C, Herrera L, Ruano E, Sinay JJ, Sánchez E, Hernández Oviedo GI, Obed F, Salgado JE, Vázquez JL, Baca M, Gutiérrez M, Centella C, Espinosa J, Martínez D, Olmedo B, Ojeda Espinoza CE, Núñez R, Haylock M, Benavides H, Mayorga R. 2005. Changes in precipitation and temperature extremes in Central America and northern South America, 1961-2003. Journal of Geophysical Research 110: D23107, DOI:10.1029/2005JD006119.

Alexander LV, Zhang X, Peterson TC, Caesar J, Gleason B, Kein Tank AMG, Haylock M, Collins D, Trewin B, Rahimzadeh F, Tagipour A, Rupa Kumar K, Revadekar J, Griffiths G, Vincenr L, Stephenson DB, Burn J, Aguilar E, Brunet M, Taylor M, New M, Zhai P, Rusticucci M, Vazquez-Aguirre JL. 2006. Global observed changes in daily climate extremes of temperature and precipitation. Journal of Geophysical Research 111: D05109, DOI:10.1029/2005JD006290.

Alexandersson H. 1986. A homogeneity test applied to precipitation data. Journal of Climatology 6: 661-675.

Alexandersson H, Moberg A. 1997. Homogenization of Swedish temperature data. Part I: homogeneity test for linear trends. International Journal of Climatology 17: 25-34.

Bell JL, Sloan LC, Snyder MA. 2004. Regional changes in extreme climatic events: a future climate scenario. Journal of Climate 17: $81-87$.

Ben-Gai T, Bitan A, Manes A, Alpert P, Rubin S. 1999. Temporal and spatial trends of temperature patterns in Israel. Theoretical and Applied Climatology 64: 163-177.

Bonsal BR, Zhang X, Vincent LA, Hogg WD. 2001. Characteristics of daily and extreme temperatures over Canada. Journal of Climate 14: 1959-1976.

Braganza K, Karoly DJ, Arblaster JM. 2004. Diurnal temperature range as an index of global climate change during the twentieth century. Geophysical Research Letters 31: L13217, DOI:10.1029/2004GL019998.

Brázdil R, Budílová M, Auer I, Böhm R, Cegnar T, Faško P, Lapin M, Gajić-Eapka M, Zaninović K, Koleva E, Niedywiedy T, Ustrnul Z, Szalai S, Weber RO. 1996. Trends of maximum and minimum daily temperatures in Central and Southeastern Europe. International Journal of Climatology 16: 765-782.

Brunet M, Aguilar E, Saladié O, Sigró J, López D. 2001. A differential response of Northeastern Spain to asymmetric trends in diurnal warming detected on a global scale. In Detecting a Modelling Climate Change, Brunet M, López D (eds). Springer-Verlag: Berlin; 95-107.

Brunet M, Jones PD, Sigró J, Saladié E, Aguilar E, Moberg A, DellaMarta PM, Lister D, Walther A, Lópex D. 2007a. Temporal and spatial temperature variability and change over Spain during 1850-2005. Journal of Geophysical Research 112: D12117, DOI: 10.1029/2006JD008249.

Brunet M, Saladié O, Jones P, Sigró J, Aguilar E, Moberg A, Lister D, Walther A, Lopez D, Almarza C. 2007b. The development of a new dataset of Spanish Daily Adjusted Temperature Series (SDATS) (1850-2003). International Journal of Climatology 26: 1777-1802.

Brunet M, Saladié O, Jones P, Sigró J, Aguilar E, Moberg A, Lister D, Walther A, Almarza C. 2008. A case-study/guidance on the development of long-term daily adjusted temperature datasets, WCDMP-66/WMO-TD-1425, Geneva, 43.

Brunetti M, Buffoni L, Mangianti F, Maugeri M, Nanni T. 2004. Temperature, precipitation and extreme events during the last century in Italy. Global and Planetary Change 40: 141-149.

Brunetti M, Maugeri M, Monti F, Nanni T. 2006. Temperature and precipitation variability in Italy in the last two centuries from homogenised instrumental time series. International Journal of Climatology 26: 345-381.

Buishand TA. 1982. Some methods for testing the homogeneity of rainfall records. Journal of Hydrology 58: 11-27.

Dai A, Trenberth KE, Karl TR. 1999. Effects of clouds, soil moisture, precipitation, and water vapour on diurnal temperature range. Journal of Climate 12: 2451-2473.

DeGaetano AT. 1996. Recent trends in Maximum and Minimum temperature threshold exceedances in the Northeastern United States. Journal of Climate 9: 1646-1660.

DeGaetano AT, Allen RJ. 2002. Trends in twentieth-century temperature extremes across the United States. Journal of Climate $\mathbf{1 5}$ 3188-3205.

Degirmendžić J, Kożuchowski K, Żmudzka E. 2004. Changes of air temperature and precipitation in Poland in the period 1951-2000 and their relationship to atmospheric circulation. International Journal of Climatology 24: 291-310.

Del Río S, Fraile R, Herrero L, Penas A. 2007. Analysis of recent trends in mean maximum and minimum temperatures in a region of the NW of Spain (Castilla y León). Theoretical and Applied Climatology 90: $1-12$.

Del Río S, Penas A, Fraile R. 2005. Analysis of recent climatic variations in Castile and Leon (Spain). Atmospheric Research 73: 69-85.

Dunn J. 2004. The influence of volcanic activity on large-scale atmospheric processes: A discussion. Weather 59: 46-49.

Easterling DR, Horton B, Jones PD, Peterson TC, Karl TR, Parker DE Salinger MJ, Razuvayev V, Plummer N, Jamason P, Folland C. 1997. Maximum and minimum temperature trends for the Globe. Science 277: 364-367.

Esteban-Parra MJ, Pozo Vázquez D, Rodrigo FS, Castro-Díez Y. 2003. Temperature and precipitation variability and trends in northern Spain in the context of the Iberian Peninsula climate. In Mediterranean Climate: Variability and Trends, Bolle HJ (ed.). Springer: Berlin; 259-276.

Ferranti L, Viterbo P. 2006. The European summer of 2003: sensitivity to soil water initial conditions. Journal of Climate 19: 3659-3680.

Founda D, Papadopoulos KH, Petrakis M, Giannakopoulos C, Good P. 2004. Analysis of mean, maximum and minimum temperature in Athens from 1897 to 2001 with emphasis on the last decade: trends, warm events and cold events. Global and Planetary Change 44: 27-38.

Frich P, Alexander LV, Della-Marta P, Gleason B, Haylock M, Klein Tank AMG, Peterson T. 2002. Observed coherent changes in climatic extremes during the second half of the twentieth century. Climate Research 19: 193-212.

Galán E, Cañada R, Fernández F, Cervera B. 2001. Annual temperature evolution in the southern plateau of Spain from the construction of regional climatic time series. In Detecting a Modelling 
Climate Change, Brunet M, López D (eds). Springer-Verlag: Berlin; 119-131.

Geng Q, Sugi M. 2003. Possible change of extratropical cyclone activity due to enhanced greenhouse gases and sulphate aerosols. Study with a high-resolution AGCM. Journal of Climate 16: 2262-2274.

Ghan ST, Shippert T. 2006. Physically based global downscaling: climate change projections for a full century. Journal of Climate 19: $1589-1604$.

Gibelin AL, Déqué M. 2003. Anthropogenic climate change over the Mediterranean region simulated by a global variable resolution model. Climate Dynamics 20: 327-339.

Gilles D, Christian W, Nicole M, Lucien H, Lurent P. 2006. Topography and recent winter rainfall regime change in temperate western European areas: a case study in the Rhine-Meuse Basin. International Journal of Climatology 26: 785-796.

Giorgi F, Bi X, Pal J. 2004. Mean, interannual variability and trends in a regional climate change experiment over Europe. II: climate change scenarios (2071-2100). Climate Dynamics 23: 839-858.

Hanna E, Jónsson T, Box JE. 2004. An analysis of Icelandic Climate since the nineteenth century. International Journal of Climatology 24: $1193-1210$.

Hasanean HM, Abdel Basset H. 2006. Variability of summer temperature over Egypt. International Journal of Climatology $\mathbf{2 6}$ 1619-1634.

Hundecha Y, Bárdossy A. 2005. Trends in daily precipitation and temperature extremes across Western Germany in the second half of the $20^{\text {th }}$ century. International Journal of Climatology 25: 1189-1202.

Jones PD, Moberg A. 2003. Hemispheric and large-scale surface air temperature variations: an extensive revision and an update to 2001. Journal of Climate 16: 206-223.

Jones PD, New M, Parker DE, Martin S, Rigor IG. 1999. Surface air temperatures and their changes over the past 150 years. Reviews of Geophysics 37: 173-199.

Jung HS, Chol Y, Oh JH, Lim GH. 2002. Recent trends in temperature and precipitation over South Korea. International Journal of Climatology 22: 1327-1337.

Kennedy J, Parker D, Coleman H. 2006. Global and regional climate in 2005. Weather 61: 215-224.

Kjellström E. 2004. Recent and future signatures of climate change in Europe. Ambio 33: 193-198.

Klein Tank AMG, Können GP. 2003. Trends in indices of daily temperature and precipitation extremes in Europe, 1946-1999. Journal of Climate 16: 3665-3680.

Klein Tank AMG, Können GP, Selten FM. 2005. Signals of anthropogenic influence on European warming as seen in the trend patterns of daily temperature variance. International Journal of Climatology 25: 1-16.

Klein Tank AMG, Wijngaard JB, Können GP, Böhm R, Demarée G, Gocheva A, Mileta M, Pashiardis S, Hejkrlik L, Kern-Hansen C, Heino R, BesseMoulin P, Müller-Westermeier G, Tzanakou M, Szalai S, Pálsdóttir T, Fitzgerald D, Rubin S, Capaldo M, Maugeri M, Leitass A, Bukantis A, Aberfeld R, Van Engelen AFV, Forland E, Mietus M, Coelho F, Mares C, Razuvaev V, Nieplova E, Cegnar T, Antonio López J, Dahlström B, Moberg A, Kirchhofer W, Ceylan A, Pachaliuk O, Alexander LV, Petrovic P. 2002. Daily datase of $20^{\text {th }}$-century surface air temperature and precipitation series for the European Climate assessment. International Journal of Climatology 22: $1441-1453$.

Knippertz P, Ulbrich U, Speth P. 2000. Changing cyclones and surface wind speeds over the North Atlantic and Europe in a transient GHG experiment. Climate Research 15: 109-122.

Kruger AC, Shongwe S. 2004. Temperature trends in South Africa: 1960-2003. International Journal of Climatology 24: 1929-1945.

Kunkel KE, Andsager K, Easterling DR. 1999. Long term trends in extreme precipitation events over United States and Canada. Journal of Climate 12: 2515-2527.

Kyselý J. 2007. Implications of enhanced persistence of atmospheric circulation for the occurrence and severity of temperature extremes. International Journal of Climatology 27: 689-695.

Kyselý J, Domonkos P. 2006. Recent increase in persistence of atmospheric circulation over Europe: comparison with long-term variations since 1881. International Journal of Climatology 26: $461-483$.

Kyung-Ja Ha, Eunho Ha. 2006. Climatic Change and interannual fluctuations in the long-term record of monthly precipitation for Seoul. International Journal of Climatology 26: 607-618.
LaDochy S, Medina R, Patzert W. 2007. Recent California climate variability: spatial and temporal patterns in temperature trends. Climate Research 33: 159-169.

Lana X, Martínez MD, Burgueño A, Serra C. Statistics of hot and cold events in Catalonia (NE Spain) for the recording period 1950-2004. Theoretical and Applied Climatology (in press), DOI 10.1007/s00704-008-0052-2.

Lionello P, Bhend J, Buzzi A, Della-Marta PM, Krichak SO, Jansà A, Maheras P, Sanna A, Trigo IF, Trigo R. 2006. Cyclones in the mediterranean region: Climatology and effects on the environment. In Mediterranean Climate Variability, Developments in Earth \& Environmental Sciences, 4, Lionello P, Malanotte-Rizzoli P, Boscolo R (eds). Elsevier: Amsterdam; 325-372.

Lionello GN, Dalan F, Elvini E. 2002. Cyclones in the Mediterranean region: the present and the doubled $\mathrm{CO}_{2}$ climate scenarios. Climate Research 22: 147-159.

Liu X, Yin ZY, Shao X, Qin N. 2006. Temporal trends and variability of daily maximum and minimum extreme temperature events and growing season length over the eastern and central Tibetan Plateau during 1961-2003. Journal of Geophysical Research 111: D19109, DOI: $10.1029 / 2005 J D 006915$.

Manton MJ, Della-Marta PM, Haylock MR, Hennessy KJ, Nicholls N, Chambers LE, Collins DA, Daw G, Finet A, Gunawan D, Inape K, Isobe $\mathrm{H}$, Kestin TS, Lefale P, Leyu CH, Lwin T, Maitrepierre L, Ouprasitwong N, Page CM, Pahalad J, Plummer N, Salinger MJ, Suppiah R, Tran B, Trewin B, Tibig I, Yee D. 2001. Trends in extreme daily rainfall and temperature in Southeast Asia and the south Pacific: 1961-1998. International Journal of Climatology 21: 269-284.

Martínez MD, Lana X, Burgueño A, Serra C. 2007. Spatial and temporal daily rainfall regime in Catalonia (NE Spain) derived from tour precipitation indices, years 1950-2000. International Journal of Climatology 27: 123-138.

McCabe GJ, Clark MP, Serreze MC. 2001. Trends in Northern Hemisphere surface cyclone frequency and intensity. Journal of Climate 14: 2763-2768.

McGuffie K, Henderson-Sellers A, Holbrook N, Kothavala Z, Balachova O, Hoekstra J. 1999. Assessing simulations of daily temperature and precipitation variability with global climate models for present and enhanced greenhouse climates. International Journal of Climatology 19: 1-26.

Meehl GA, Tebaldi C. 2004. More intense, more frequent and longer lasting heat waves in the $21^{\text {st }}$ century. Science 305: 994-997.

Mills TC. 2006. Modelling current trends in Northern Hemisphere temperatures. International Journal of Climatology 26: 867-884.

Miró JJ, Estrela MJ, Millán M. 2006. Summer temperature trends in a Mediterranean area (Valencia region). International Journal of Climatology 26: 1051-1073.

Mitchell JA, Dzerdzeevskii B, Flohn H, Hofmeyr WL, Lamb HH, Rao KN, Wallén CC. 1966. Climatic Change, Technical Note 79, World meteorological Organization: Geneva, 79.

Moberg A, Jones P. 2005. Trends in indices for extremes in daily temperature and precipitation in Central and Western Europe, 1901-1999. International Journal of Climatology 25: 1149-1171.

Moberg A, Jones PD, Lister D, Walther A, Brunet M, Jacobeit J, Alexander LV, Della-Marta PM, Luterbacher J, Yiou P, Chen D, Klein Tank AMG, Saladié O, Sigró J, Aguilar E, Alexandersson H, Almarza C, Auer I, Barriendos M, Begert M, Bergström H, Böhm R, Butler CJ, Caesar J, Drebs A, Founda D, Gerstengarbe FW, Micela G, Maugeri M, Österle H, Pandzic K, Petrakis M, Srnec L, Tolasz R, Tuomenvirta H, Werner PC, Linderholm H, Philipp A, Wanner H, Xopalki E. 2006. Indices for daily temperature and precipitation extremes in Europe analyzed for the period 1901-2000. Journal of Geophysical Research 111: D22106, DOI:10.1029/2006JD007103.

New M, Hewiston B, Stephenson DB, Tsiga A, Kruger A, Manhique A, Gomez B, Coelho CAS, Ntiki D, Kululanga E, Mbambalala E, Adesina F, Saleh H, Kanyanga J, Adosi J, Bulane L, Fortunata L, Mdoka ML, Lajoie R. 2006. Evidence of trends in daily climate extremes over southern and West Africa. Journal of Geophysical Research 111: D14102, DOI:10.1029/2005JD006289.

Oñate JJ, Pou A. 1996. Temperature variations in Spain since 1901: a preliminary study. International Journal of Climatology 16: 805-815.

Otterman J, Angell JK, Ardizzone J, Atlas R, Schubert S, Starr D, Wu ML. 2002. Nort-Atlantic surface winds examined as the source of winter warming in Europe. Geophysical Research Letters 29: 1912, DOI:10.1029/2002GL015256. 
Parker DE, Wilson H, Jones PD, Christy JR, Folland CK. 1996. The impact of Mount Pinatubo on world-wide temperatures. International Journal of Climatology 16: 487-497.

Pettitt AN. 1979. A non-parametric approach to the change-point problem. Journal of Applied Statistics 28(2): 126-135.

Pinto JG, Ulbrich U, Leckebusch GC, Spangehl T, Reyers M, Zacharias S. 2007. Changes in storm track and cyclone activity in three SRES ensemble experiments with the ECHAM5/MPI-OM1 GCM. Climate Dynamics 29: 195-210.

Quintana-Gómez RA. 1999. Trends of maximum and minimum temperatures in Northern South America. Journal of Climate 12: $2104-2112$.

Räisänen J, Hansson U, Ullerstig A, Döscher R, Grahan LP, Jones C, Meier HEM, Samuelsson P, Willén U. 2004. European climate in the late twenty-first century: regional simulations with two driving global models and two forcing scenarios. Climate Dynamics 22: 13-31.

Rebetez M, Reinhard M. 2008. Monthly air temperature trends in Switzerland 1901-2000 and 1975-2004. Theoretical and Applied Climatology 91: 27-34.

Redaño A, Cruz J, Lorente J. 1991. Main features of the sea-breeze in Barcelona. Meteorology and Atmospheric Physics 46: 175-179.

Robock A. 2000. Volcanic eruptions and climate. Reviews of Geophysics 38: 191-219.

Sáenz J, Rodríguez-Puebla C, Fernández J, Zubillaga J. 2001. Interpretation of interanual winter temperature variations over southwestern Europe. Journal of Geophysical Research 106(D18): 20641-20651.

Salat J, Pascual J. 2006. Principales tendencias climatologicas en el Mediterráneo nordoccidental a partir de más de 30 años de observaciones oceanográficas y meteorológicas en la costa catalana. Publicaciones de la Asociación Española de Climatología (AEC), Serie A 5: 283-290.

Salinger MJ. 2005. Climate variability: Past, present and future. An overview. Climatic Change 70: 9-29.

Salinger MJ, Griffiths GM. 2001. Trends in New Zealand daily temperatures and rainfall extremes. International Journal of Climatology 21: 1437-1452.

Sánchez E, Gallardo C, Gaertner MA, Arribas A, Castro M. 2004. Future climate extreme events in the Mediterranean simulated by a regional climate model: a first approach. Global and Planetary Change 44: $163-180$.

Sánchez-Lorenzo A, Calbó J, Martín-Vide J, Prohom M, Llach M. 2006. Evolución temporal de la nubosidad en el sector costero catalán desde principios del siglo XX. Publicaciones de la Asociación Española de Climatología (AEC), Serie A 5: 291-300.

Scafetta N, West BJ. 2006a. Phenomenological solar contribution to the 1900-2000 global surface warming. Geophysical Research Letters 33: L05708, DOI:10.1029/2005GL025539.

Scafetta N, West BJ. 2006b. Phenomenological solar signature in 400 years of reconstructed Northern Hemisphere temperature record. Geophysical Research Letters 33: L17718, DOI:10.1029/2006 GL027142.

Schönwiese CD, Rapp J. 1997. Climatic trend Atlas of Europe based on observations, 1891-1990. Kluwer Academic Publishers: Dordrecht; 228.

Schubert M, Perlwitz J, Blender R, Fraedrich K, Lunkeit F. 1998. North Atlantic cyclones in $\mathrm{CO}_{2}$-induced warm climate simulations: frequency, intensity and tracks. Climate Dynamics 14: 827-837.

Sen PK. 1968. Estimates of the regression coefficients based on Kendall's tau. Journal of the American Statistical Association 63: $1379-1389$

Serra C, Burgueño A, Lana X. 2001. Analysis of maximum and minimum daily temperatures recorded at Fabra Observatory (Barcelona, NE Spain) in the period 1917-1998. International Journal of Climatology 21: 617-636.

Serra C, Burgueño A, Martínez MD, Lana X. 2006. Trends in dry spells across Catalonia (NE Spain) during the second half of the $20^{\text {th }}$ century. Theoretical and Applied Climatology 85: 165-183.

Sneyers R. 1990. On the Statistical Analysis of Series of Observations, Vol. 415. WMO, World Meteorological Organization: Geneve; 192.
Stone DA, Weaver AJ. 2002. Daily maximum and minimum temperature trends in a climate model. Geophysical Research Letters 29(9): 1356, DOI:10.1029/2001GL014556.

Stone DA, Weaver AJ. 2003. Factors contributing to diurnal temperature range trends in twentieth and twenty-first century simulations of the CCCma coupled model. Climate Dynamics 20: $435-445$.

Tarhule A, Woo M. 1998. Changes in rainfall characteristics in northern Nigeria. International Journal of Climatology 18: 1261-1271.

Tomé AR, Miranda PMA. 2004. Piecewise linear fitting and trend changing points of climate parameters. Geophysical Research Letters 31: L02207, DOI:10.1029/2003GL019100.

Tomozeiu R, Busuioc A, Stefan S. 2002. Changes in seasonal mean maximum air temperature in Romania and their connection with large-scale circulation. International Journal of Climatology 22: $1181-1196$.

Toreti A, Desiato F. 2008. Temperature trend over Italy from 1961 to 2004. Theoretical and Applied Climatology 91: 51-58.

Trenberth KE, Jones PD, Ambenje P, Bojariu R, Easterling D, Klein Tank A, Parker D, Rahimzadeh F, Renwick JA, Rusticucci M, Soden B, Zhai P. 2007. Observations: Surface and atmospheric climate change. In Climate Change 2007: The Physics Science Basis. Contribution of Working Group I to the Fourth Assessment Report of the Intergovernmental Panel on Climate Change, Solomon S, Qin D, Manning M, Chen Z, Marquis M, Averyt KB, Tignor M, Miller HL (eds). Cambridge University Press: Cambridge, New York.

Ulbrich U, Christoph M. 1999. A shift of the NAO and increasing storm track activity over Europe due to anthropogenic greenhouse gas forcing. Climate Dynamics 15: 551-559.

Vargas-Yañez M, Salat J, Fernández de Puelles ML, López-Jurado JL, Pascual J, Ramírez T, Cortés D, Franco I. 2005. Trends and time variability in the northern continental shelf of the western Mediterranean. Journal of Geophysical Research 110: C10019, DOI:10.1029/2004JC002799.

Vautard R, Yiou P, D’Andrea F, de Noblet N, Viovy N, Cassou C, Polcher J, Ciais P, Kageyama M, Fan Y. 2007. Summertime European heat and drought waves induced by wintertime Mediterranean rainfall deficit. Geophysical Research Letters 34: L07711, DOI:10.1029/2006GL028001.

Vincent LA, Zhang X, Bonsal BR, Hogg WD. 2002. Homogenisation of daily temperatures over Canada. Journal of Climate 15: $1322-1324$.

Von Neumann J. 1941. Distribution of the ratio of the mean square successive difference to the variance. Annals of Mathematical Statistics 13: 367-395.

Warren SG, Eastman RM, Hahn CJ. 2007. A survey of changes in cloud cover and cloud types over land from surface observations, 1971-1996. Journal of Climate 20: 717-738.

Wijngaard JB, Klein Tank MG, Können GP. 2003. Homogeneity of $20^{\text {th }}$ century European daily temperature and precipitation series. International Journal of Climatology 23: 679-692.

Wild M, Ohmura A, Makowski K. 2007. Impact on global dimming and brightening on global warming. Geophysical Research Letters 34: L03710, DOI:10.1029/2006GL028031.

Wulfmeyer V, Henning-Müller I. 2006. The climate station of the University of Hohenheim: analyses of air temperature and precipitation time series since 1878. International Journal of Climatology 26: $113-138$.

Zhai P, Pan X. 2003. Trends in temperature extremes during 1951-1999 in China. Geophysical Research Letters 30: 1913, DOI:10.1029/2003GL018004.

Zhang X, Walsh JE, Zhang J, Bhatt US, Ikeda M. 2004a. Climatology and interannual variability of Arctic cyclone activity: 1948-2002. Journal of Climate 17: 2300-2317.

Zhang X, Zwiers FW, Li G. 2004b. Monte Carlo experiments on the detection of trends in extreme values. Journal of Climate 17: $1945-1952$. 